\title{
Traumatic Brain Injury: An Age-Dependent View of Post-Traumatic Neuroinflammation and Its Treatment
}

\author{
Clément Delage $^{1, * \mathbb{D}}$, Toufik Taib ${ }^{2}$, Célia Mamma ${ }^{2}$, Dominique Lerouet ${ }^{1}$ (D) and Valérie C. Besson ${ }^{1}(\mathbb{D}$ \\ 1 Université de Paris, Inserm UMR-S 1144-Optimisation Thérapeutique en Neuropsychopharmacologie, \\ Faculté de Pharmacie de Paris, 4 Avenue de l'Observatoire, 75006 Paris, France: \\ dominique.lerouet@u-paris.fr (D.L.); valerie.besson@u-paris.fr (V.C.B.) \\ 2 Université Paris Descartes, EA4475-Pharmacologie de la Circulation Cérébrale, Faculté de Pharmacie de \\ Paris, 4 Avenue de l'Observatoire, 75006 Paris, France; toufikpharma@gmail.com (T.T.); \\ cyliamam@gmail.com (C.M.) \\ * Correspondence: clement.delage@u-paris.fr; Tel.: +33-153-739-786
}

check for updates

Citation: Delage, C.; Taib, T.;

Mamma, C.; Lerouet, D.; Besson, V.C.

Traumatic Brain Injury: An

Age-Dependent View of

Post-Traumatic Neuroinflammation and Its Treatment. Pharmaceutics 2021, 13, 1624. https://doi.org/10.3390/ pharmaceutics13101624

Academic Editor: Maria

A. Tikhonova

Received: 20 August 2021

Accepted: 26 September 2021

Published: 6 October 2021

Publisher's Note: MDPI stays neutral with regard to jurisdictional claims in published maps and institutional affiliations.

Copyright: (c) 2021 by the authors. Licensee MDPI, Basel, Switzerland. This article is an open access article distributed under the terms and conditions of the Creative Commons Attribution (CC BY) license (https:// creativecommons.org/licenses/by/ $4.0 /)$.
Abstract: Traumatic brain injury (TBI) is a leading cause of death and disability all over the world. TBI leads to (1) an inflammatory response, (2) white matter injuries and (3) neurodegenerative pathologies in the long term. In humans, TBI occurs most often in children and adolescents or in the elderly, and it is well known that immune responses and the neuroregenerative capacities of the brain, among other factors, vary over a lifetime. Thus, age-at-injury can influence the consequences of TBI. Furthermore, age-at-injury also influences the pharmacological effects of drugs. However, the postTBI inflammatory, neuronal and functional consequences have been mostly studied in experimental young adult animal models. The specificity and the mechanisms underlying the consequences of TBI and pharmacological responses are poorly understood in extreme ages. In this review, we detail the variations of these age-dependent inflammatory responses and consequences after TBI, from an experimental point of view. We investigate the evolution of microglial, astrocyte and other immune cells responses, and the consequences in terms of neuronal death and functional deficits in neonates, juvenile, adolescent and aged male animals, following a single TBI. We also describe the pharmacological responses to anti-inflammatory or neuroprotective agents, highlighting the need for an age-specific approach to the development of therapies of TBI.

Keywords: neuroinflammation; traumatic brain injury; preclinical; neonates; juvenile; adolescent; aged; preclinical; neuroprotection

\section{Traumatic Brain Injury}

The aim of this review is to present the principal elements of traumatic brain injury (TBI), post-traumatic neuroinflammation, and to describe its evolution and consequences depending on age (neonates, juvenile, adolescent and aged), based on preclinical data.

\subsection{Definition}

TBI is defined as an alteration in brain function, or other evidence of brain pathology, caused by an external force [1]. Characterized by a great heterogeneity in terms of etiology, physiopathology, severity and symptomatology, TBI is considered the most complex disease in our most complex organ [2]. TBI is now also considered a chronic condition, as it can progress not only for hours or days but also for years. Depending on the injured brain regions and the extent of these lesions and symptoms, TBI may be classified as mild, moderate or severe. Mild TBI represents 80 to $90 \%$ of all TBI [3,4]. The proportion of severe TBI is lower, but is characterized by a higher mortality rate, of 30 to $40 \%$. 


\subsection{Epidemiology}

More than 50 million TBI cases occur each year worldwide and about half of the world population will undergo, at least, one TBI in their lifetime [4]. The two main populations sustaining TBI are people aged $<4$ years and those aged $>75$ years. People between 5 and 25 years are also more likely to sustain TBI, but to a lesser extent. TBI may originate from road traffic incidents, falls, sports, terrorism and military conflicts. A recent systematic review and meta-analyses of articles describing the epidemiology of TBI in 16 European countries showed that the first two causes are the most frequent, with falls being reported more frequently than motor vehicle accidents [5]. However, within the studies that mainly focus on more severe TBI, the latter remain dominant as a cause of injury. Moreover, a correlation was found between the cause of injury and age, with falls being most common in children and elderly subpopulations, while road traffic incidents are the most frequent in young adults. TBI causes vary greatly between countries and regions. In low- and middle-income countries, the rising burden of TBI due to the increase of road traffic incidents mainly affects youths, while in high-income countries the changing epidemiology of TBI is related to a high and increasing incidence in infants and elderly people. Lastly, sports, such as rugby and boxing, and military conflicts also increase the number of TBIs $[5,6]$.

\subsection{Neuroinflammation after TBI in Young Adults}

TBI leads to primary lesions resulting directly from an impact and caused by mechanical forces. These physical injuries will trigger physiopathological and biochemical cascades, leading to secondary lesions [7], which tend to exacerbate the initial damages in the hours, days, months or even years after the impact [8]. Among these secondary lesions, the "sterile" (as it is not caused by pathogens) inflammatory response is called neuroinflammation. Neuroinflammation is a complex, nonspecific and coordinated response that appears during the acute phase of TBI and can last for years. Neuroinflammation is characterized by (1) the activation of glial cells by cellular membrane disruption components like the damage associated molecular patterns (DAMPs) and/or mitochondrial dysfunction components, and/or blood components leakage from the altered blood-brain barrier (BBB); (2) the release of pro- and anti-inflammatory cytokines; (3) the infiltration of blood cells through BBB, sometimes injured by the impact [9].

\subsubsection{Immune Glial Cells}

Activated microglia and astrocytes phagocyte cellular debris and modulate the other immune cells responses. In an inflammatory context, these cells undergo morphological changes and form a glial scar, constituting a physical barrier that isolates the lesion area from other healthy brain structures. Glial cells can be activated directly by brain lesions, but also by perivascular glial cells and infiltrating immune cells. They also can be activated by their own secreted factors in an autocrine and paracrine way, which will then amplify and self-sustain the inflammatory response $[10,11]$.

\section{Microglia}

Microglial activation

Microglia are the specific resident macrophage of the central nervous system (CNS) with phagocytosis and antigen presentation capabilities. Microglia are the most abundant mononuclear phagocyte in the CNS and accounts for about $10 \%$ of the total CNS cell population in adults [12]. Under physiological conditions, microglia are ramified and very dynamic, constantly ensuring the homeostasis of its environment. Its ramifications monitor the cerebral parenchyma to remove tissue debris, excess metabolites, or any other component that may disrupt CNS homeostasis by phagocytosis. In addition, microglia are essential for neuronal development and function. It not only participates in the control of cell death and the elimination of defective synapses, but also contributes to neurogenesis, transmission and synaptic plasticity. In the absence of brain injury, microglia are maintained in the "surveilling" state through "off" signals mainly from neurons [13]. 
Depending on stimuli to which microglia are subjected, they will differentiate into different activation state, leading to microglial phenotypes or the notion of microglial polarization. As microglial activation is outside the scope of this review and has already been widely described in exhaustive reviews $[13,14]$, we will only briefly underline the different microglial phenotypes. Activated microglia are commonly categorized by two phenotypes, M1, considered pro-inflammatory, and M2, considered anti-inflammatory. The different microglial phenotypes work together to control inflammation, remove debris and promote tissue repair and remodeling. The action of pro-inflammatory molecules on microglia directs them towards the pro-inflammatory M1 phenotype, which produces pro-inflammatory cytokines (TNF $\alpha$, IL-1 $\beta$, IL-6, -12, -18, -23, IFN $\gamma$ ) and chemokines (CCL2, 5 and 20, CXCL1, 9 and 10) as well as reactive oxygen species (ROS). In contrast, in response to anti-inflammatory cytokines (IL-4, -10 and -13 , TGF $\beta$ ), microglia adopt an alternative activation phenotype designated M2. This phenotype has anti-inflammatory properties and participates in tissue repair and regeneration. M2 subphenotypes have also been described, with an "alternative" M2a, an "intermediate" M2b and a "deactivated" M2c phenotype. However, as almost no study explored M2 subtypes expression in TBI other than in young adult rodents, we will not detail their role in this review [13]. Although microglial polarization is well described in in vitro models, the proof of existence of two distinct populations M1 and M2 in vivo is currently under debate [15]. Faced with very complex tissue signals, microglia can also adopt a mixed phenotype called "Mtrans", expressing both M1 and M2 markers [16]. Indeed, a continuum of microglial activation, expressing different microglial states markers, is observed after a TBI [14].

Microglial activation consequences in vitro

In vitro, microglial phenotypes M1 and M2 can be induced by the application of respectively pro-inflammatory and anti-inflammatory cytokines on primary culture of microglial cells.

The M1 phenotype inhibits the differentiation of neural progenitor stem cell (NPC) into mature oligodendrocytes [17], exacerbates neuronal and oligodendrocyte death following oxygen and glucose privation [18-21] and secretes pro-inflammatory cytokines (such as $\mathrm{TNF} \alpha, \mathrm{IL}-1 \beta,-2$ and IFN $\gamma$ ) which induce apoptosis in mature oligodendrocytes [22].

Conversely, the M2 microglia phenotype exerts its neuroprotective activity by promoting neurogenesis through the secretion of brain-derived neurotrophic factor (BDNF), nerve growth factor (NGF) and basic fibroblast growth factor (FGF-2) [16], and neural-progenitors differentiation [17]. M2 phenotype has also a protective effect on oligodendrocytes cell death induced by oxygen and glucose deprivation [21].

Moreover, it has been shown that myelin debris resulting from neuronal death also inhibit differentiation of oligodendrocyte progenitor cells [23,24] and activate microglia [25], in a pro-inflammatory [26] and neurotoxic [27] phenotype. Myelin debris inhibit neuronal growth and axonal regeneration [28]. Myelin debris do not seem to have an exclusively deleterious effect, as macrophages phagocytizing myelin debris present rather anti-inflammatory properties [29]. However, only a few studies have investigated the implications of myelin debris in post-TBI neuroinflammation.

Microglial activation in vivo in young adult

In vivo, in young adults, microglial activation occurs from $4 \mathrm{~h}$ [30] to one year postTBI [31]. Different subsets of microglia increase during the acute and chronic phases after TBI. The M1 phenotype appears early, from the first hours post-TBI [32]. The M2 phenotype appears later [19] and transiently [16,19,32-35]. Thus, after a M1/M2 cohabitation phase with the presence of a mixed activated population, up to 5 weeks post-TBI [10,36], the M1 phenotype eventually predominates [33] and remains the only active phenotype [19].

Additionally, some studies showed the presence of "Mtrans" microglia coexpressing M1 markers such as TGF $\beta$, CD16 and CD32, and M2 markers such as Arginase1 and NOS2 from 1 to 7 days post-TBI [16,35]. 


\section{Astrocytes}

Located between endothelial cells and neurons, astrocytes help maintain the BBB integrity by forming astrocyte feet surrounding endothelial cells [37]. They also participate in neuronal homeostasis by modulating neurotransmitter concentrations such as glutamate and promoting the formation and function of synapses [38]. Astrocytic activation following brain damage is designated by the term "astrogliosis" [39]. Once activated, astrocytes proliferate, change their morphology with hypertrophy of cell body and processes, and produce inflammatory mediators and trophic factors [40]. They also migrate to the lesion site and form the glial scar, which prevents the diffusion of pro-inflammatory and cytotoxic molecules to surrounding healthy tissues and thus limits the extension of the inflammatory process outside the lesion area [38].

As for microglial activation, astrogliosis has been found to be complex, since both beneficial and deleterious effects have been attributed to them [41]. Indeed, neuroinflammation induces two different types of reactive astrocytes that can be termed "A1" and "A2" based on M1 and M2 macrophages nomenclature. The A1 phenotype loses most normal astrocyte functions but gains neurotoxic properties, rapidly killing neurons and mature differentiated oligodendrocytes. Oppositely, the A2 phenotype appears neuroprotective [42]. If the A1 phenotype has been reported following TBI [43], its effects following TBI have nonetheless not yet been studied. However, as for the microglial phenotype denomination, recent studies suggest that there is no reactive astrocytic polarization into simple binary phenotypes. Reactive astrocytes may adopt multiple states depending on context, with only a fraction of common changes between different states [44].

In vivo, in young adults animals, astrogliosis appears in the hours following the impact and can last for 14 days to 60 days [30,45-47].

\subsubsection{Cytokines}

Cytokines can be secreted by all cellular actors of inflammation, as well as by neurons, but microglia remains their main source in the CNS [48]. In addition to their role in inflammation, cytokines are essential for CNS development and function [45]. Cytokines, and their role, have already been widely described in well-documented reviews [49-51] so we will only briefly describe the main different cytokines implicated in neuroinflammation.

Pro-inflammatory cytokines that initiate inflammation include IL-1 $\beta,-6$ and -18, TNF $\alpha$ and IFN $\gamma$. These cytokines are first released by glial cells after tissue injury and:

- promote the activation and proliferation of astrocytes and microglia;

- contribute to the formation of edema and neuronal death and inhibit neuronal regeneration;

- potentiate the permeability of the BBB and increase the expression of cell adhesion molecules and chemokines to recruit peripheral immune cells;

- $\quad$ stimulate the production of other pro-inflammatory cytokines, or enzymes such as cyclooxygenase- 2 or phospholipase A2.

The effects of pro-inflammatory cytokines are not so settled and unilateral, and contribute to the complexity of the neuroinflammation. Several studies reported detrimental effects of inhibiting pro-inflammatory cytokines, meaning they could confer beneficial and long-term protective effects [45].

Anti-inflammatory cytokines, such as IL-4, $-10,-13$, and TGF $\beta$, appear after the proinflammatory ones to modulate and reduce inflammation by mechanisms that are still not fully elucidated [8].

Cytokine expression in vivo following TBI in young adult animals has already been widely studied and reviewed [52]. Briefly, overall cytokine expression increases from 1 $\mathrm{h}$ following TBI and peaks between 2 and $24 \mathrm{~h}$ following injury [52]. IL-1 $\beta$ expression increases within $1 \mathrm{~h}$ and peaks between 12 and $24 \mathrm{~h}$ following TBI [53-57]. TNF $\alpha$ expression increases within $1 \mathrm{~h}$ and peaks between 4 and $8 \mathrm{~h}$ following TBI [58-62]. IL-6 expression increases at $1 \mathrm{~h}$ and peaks between 2 and $8 \mathrm{~h}$ following TBI [58,59,63-67]. IL-10 expression increases rapidly and peaks between 4 and $20 \mathrm{~h}$ following TBI [68]. 


\subsubsection{Peripheral Immune Cell Infiltration}

Some cytokines-chemokines-are capable of regulating the activation and migration of leukocytes through the BBB, already potentially altered by the impact of TBI [9]. Leukocytes, thus recruited by the chemotactic molecules, roll along the endothelium, adhere to the latter through adhesion molecules (ICAM-1), then pass through the BBB via the intercellular junctions [69]. In brain parenchyma, they reinforce and stimulate the inflammatory activity of CNS cells, and contribute to the recruitment of new peripheral immune cells. It contributes to cytotoxicity, neuronal death, glial activation and inflammatory mediators production that disrupt the BBB permeability $[9,70]$. In vivo in young adults animals, leukocytes infiltration appears to be very fast, from a few hours after the impact [70,71], but the number of macrophages begins to decrease after only a few days TBI [33].

\subsection{Neuroinflammation Consequences in Young Adults}

Although neuroinflammation is essential for exogenous pathogens' elimination, tissue repair and neuroregeneration after TBI, this "double-edged sword" inflammatory response [72] amplifies post-TBI primary and secondary lesions, especially neuronal death and white matter injuries (WMI) [8,73]. Due to the spatio-temporal correlation between (1) microglial activation and axonal lesions [74], (2) the early increase of IL-1 $\beta$ brain expression and severity of the TBI $[45,48,49]$, and (3) the frequent association between chronic microglial activation and white and gray matter degeneration [31,75-77], chronic neuroinflammation seems to contribute to the long-term neurodegeneration following TBI [31,78].

Cellular death and white matter injuries

It has been demonstrated that the corpus callosum is altered, with white matter thinning and decreased myelin staining, at the short and long terms in rodent models of TBI, [79-82]. An oligodendrocyte death has been observed up to 21 days after TBI [83]. As oligodendrocytes are responsible for myelin synthesis, their destruction induces demyelination that will slow nerve conduction and favor axonal degeneration and WMI $[31,76,84,85]$. Oligodendrocyte death could be due to the M1 microglial phenotype. This hypothesis is supported by the correlation between the number of microglia and the severity of demyelination and axonal damages [19], and the preservation of white matter integrity when decreasing M1 activation [21]. The M1 microglial phenotype would thus be responsible of myelin decrease at short-(2 days) [85], mid-(14 days) [32] and long-term (2 months) post-injury [80]. However, oligodendrocytes are highly vulnerable to oxidative stress, excitotoxicity and hypoxia consecutive to TBI primary brain damages, which promotes their apoptosis $[22,86,87]$. Thus, M1 microglia potentiate an already present post-TBI oligodendrocyte death and neurodegeneration due to the TBI biochemical content [13]. However, another hypothesis to the decrease of oligodendrocytes could be proposed, since the death of oligodendrocytes after a TBI is associated with demyelination [32]. The destruction of neuronal axons results in the destruction of myelin, which could be the cause of oligodendrocyte death.

In a TBI context, microglial activation is associated to the presence of myelin debris $[74,85,88]$. As activated microglia aggravate oligodendrocytes death and demyelination [32] it could induce myelin debris production, suggesting a vicious circle of neuroinflammatory amplifying and thus maintaining of the M1 phenotype [26] and its deleterious neuroinflammation $[25,27,89,90]$. Furthermore, as myelin is rich in lipids, WMI such as demyelination may be associated with an altered lipid profile near the lesion [91,92], in other brain regions $[93,94]$ and in blood [95]. This has been confirmed by a lipidomic study, revealing modifications in the lipid profile of corpus callosum following a TBI [96]. A positive correlation was also observed between the increase in circulating sphingolipids and lesion volume, suggesting a possible use of the plasma level of sphingolipids as a biomarker for the diagnosis of brain lesions [97].

Demyelination is, however, not a definitive phenomenon, as remyelination and proliferation of oligodendrocyte progenitor cells has been observed following TBI [22,83,85,98], whose onset coincides with the transition from the M1 phenotype to the M2 phenotype [99]. 
Consistent with the in vitro effects of the M2 phenotype previously described, its increase is associated with preservation of the integrity of the white matter, decreases in axon demyelination and improvement in nerve conduction [21]. This phenomenon could explain why an undifferentiated total depletion of microglial phenotype does not always demonstrate protective effects [100,101].

Infiltrating immune cells also contribute to post-traumatic chronic inflammation and its functional consequences, since inhibition of chemotaxis, or polymorphonuclear neutrophils depletion induces a decrease in cytokine production, cerebral oedema, injury volume and tissue loss, microglia/macrophage activation, cellular death and neurobehavioral deficits [102-104].

Epileptogenesis

Post-traumatic epilepsy is a well-known complication of TBI, experimentally evidenced in rodents both at the short and long terms [105,106]. Recently, the occurrence of epileptic seizures has been linked to the presence of neuroinflammation. Experimental studies also showed that the development of these seizures depends on the severity of neuroinflammation [107].

Specifically, inflammatory mediators released by brain cells, or infiltrating peripheral immune cells, following TBI activate cognate receptors expressed by neurons and induce transcriptional and post- translational changes in glutamate and GABA receptors and in ion channels [107]. The oxidative stress, induced by TBI through the generation of reactive oxygen species by activated immune cells and suffering neurons, also induces neuronal excitability [108]. Finally, BBB lesion and astrocytic activation contribute to epileptogenesis through water homeostasis disruption [109].

Epileptic seizures, thus generated, induce the release of neuronal death and reactive oxygen species, inflammatory mediators, released by immune cells or activated vessels, and BBB alteration, which in turn favors the inflammatory process [107]. This vicious circle maintains and potentiates post-TBI neuroinflammation.

\section{Functional deficits}

The WMI induced by neuroinflammation is increasingly recognized as responsible for long-term disabilities consecutive to TBI. Experimentally, in young adults animals, the extent of WMI has been shown to correlate with the degree of functional deficits months after injury $[110,111]$. These long-term functional deficits can be evaluated in several different ways [112]. Thus, motor coordination deficits following TBI have been observed through various tests, such as balance beam [113], beam walking [114], or rotarod tests [115]. TBI also induces memory deficits, as acquisition and reference memory deficits have been evidenced by the Morris water maze test [116] or the radial arm maze test [117]. Exploration behavior is also impaired after TBI, as evidenced by the novel object recognition test [118]. Concerning emotional functions, an alteration in anxiety-like behavior through the open-field test [119] and a depression-like behavior, through the forced swim test, have been observed [120].

\subsection{Therapeutic Strategies}

The medical management of TBI is only symptomatic. It mainly consists in the treatment of intracranial hypertension and convulsive status epilepticus, the maintenance and cessation of sedation and analgesia in patients [121]. To date, no therapeutic strategy is available and used to prevent the onset and spread of secondary lesions in humans.

Several pharmacological strategies have been tested in pre-clinical studies. They aim of reducing the progression of secondary brain lesions by administering anti-inflammatory or neuroprotective agents before or after TBI. Some therapeutic strategies also aim to inhibit the post-TBI epileptogenesis process to avoid the potentiation of neuroinflammation and the consequences of epileptic seizure. Thus, therapeutic strategies are more or less effective depending on the agent tested, the schedule of administration and the experimental model used, and have been the subject of well-documented reviews [122,123]. To date, none 
of them have yet passed the clinical development stage and been proven effective in humans [124].

Recently, it has appeared that the extent of the consequences of TBI depends not only on the severity of the mechanical impact, but also on patient-specific factors such as age [125] or sex [126]. Specifically, different microglial subtypes have been described as depending on age $[127,128]$, presenting different characteristics and functions. Thus, as it has been suggested by some experimental studies [129], we could assume that the variation in the consequences of TBI due to age might depend on the variability of the inflammatory response. As Simon et al. highlighted in their very exhaustive review on postTBI neuroinflammation, "there is a need to define the inflammatory phenotypes of our patients on the basis of injury characteristics such as patient age, sex, genetic predisposition, presence or absence of secondary insults, and serum, CSF and/or imaging biomarkers" [130].

The purpose of this review is to detail the variations of this age-dependent inflammatory response and its consequences, from an experimental point of view. TBI has been widely studied in young adults, which is usually used as the "reference" age to compare to other ages of TBI patients. Thus, we will not describe the evolution of the neuroinflammation response to TBI in young adults more than in $\$ 1.4$-neuroinflammation consequences in the young adult. We will focus on the consequences of TBI on neonates, juvenile/adolescent and old-aged animals, based on preclinical studies, as it corresponds to the age of the peak prevalence of TBI in humans (Figure 1). This review will only focus on single and not-repeated TBI, and will not investigate variation by sex, which is also suspected to influence the neuroinflammation response but has already been the subject well-documented review [126]. Since, to our knowledge only one study has been performed on both sexes in adolescents, we will only consider studies performed on males.

\section{Post-Traumatic Neuroinflammation and Its Consequences In Vivo}

Based on brain and metabolism development and sexual maturation, we considered rodents aged 7 postnatal days (P) as neonates, P17 to P21 as juvenile and P35 to P42 as adolescent. Rodents aged 12 to 18 months $(\mathrm{M})$ were considered young adults and, those aged M22 to M24, as aged (Figure 1). We also included two studies of rabbit TBI models, as they are recent studies and as white matter development, microglial presence in the white matter tracts, and the pattern of brain growth is paralleled between rabbits and humans. Additionally, the rabbit brain has more anatomical similarity to the human brain than the lissencephalic rodent brain [131].

\subsection{Neonates}

Although infants are one of the most important populations that sustain TBI, only a few studies have explored its consequences in neonatal animals, and none have studied the long-term neurological and functional consequences thereof. All these studies are listed in Table 1. A closer look at pediatric TBI is needed, as the infantile period is characterized by several crucial developmental processes (brain growth, synaptogenesis, myelination...). In mice and rats, this developmental period occurs within the first three postnatal weeks [139]. In the literature, only P7 and P11 animals have been studied, as it is the period of maximal neuronal proliferation [139]. Processes at risk during this phase include glial proliferation and myelination, the explosive increase of dendritic complexity, the establishment of synaptic connections, and the reorganization of events [139] (Figure 1). 


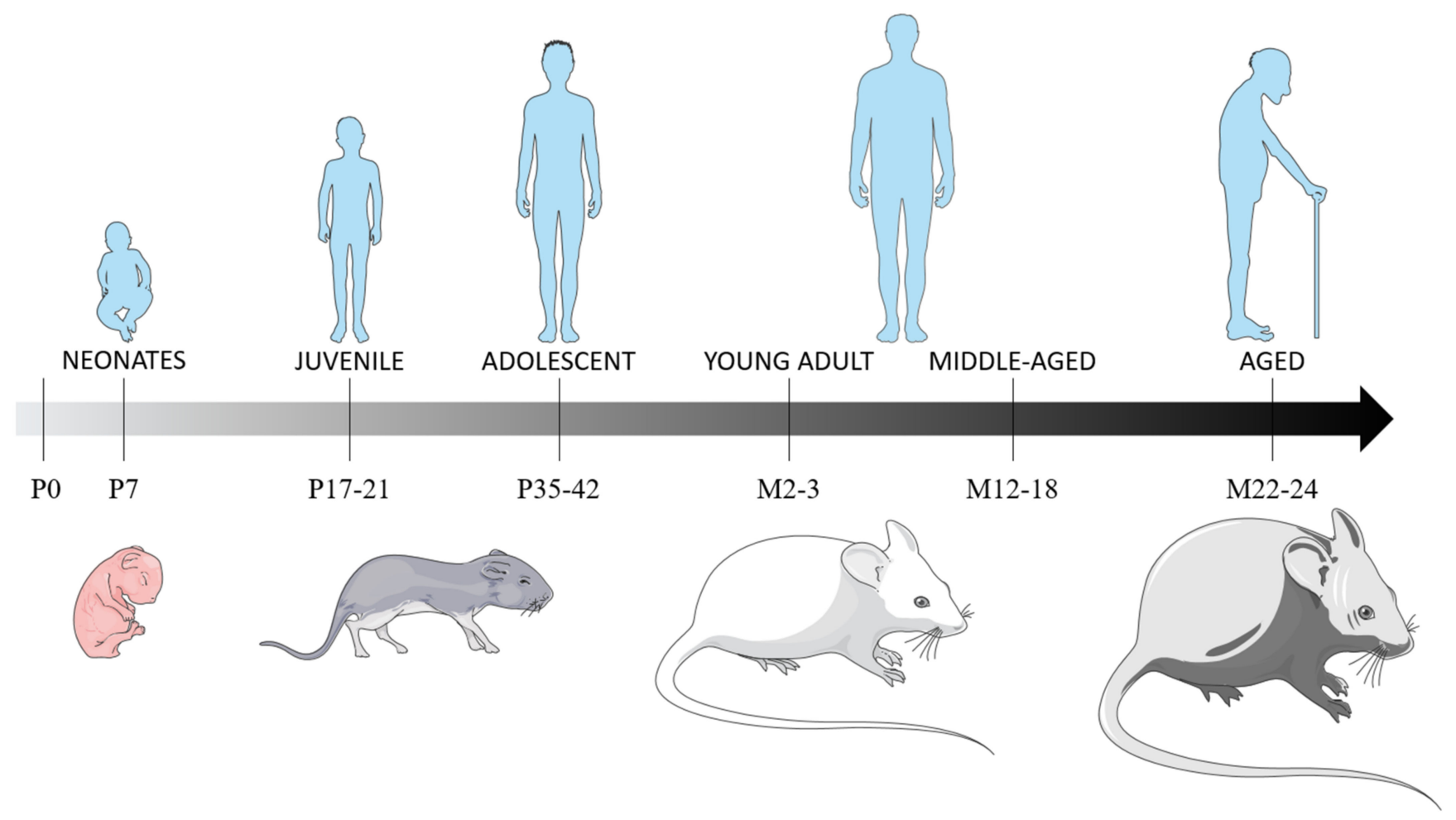

Figure 1. Rats' and mice' age correspondence with humans, based on brain and metabolism development, and sexual maturation. The brain developmental period occurs during the first three post-natal weeks, with the main brain growthspurt period in the first post-natal week, a period of maximal neuronal proliferation, glial proliferation and the establishment of synaptic connections [132,133]. At P11, the neurological development in rodents is equivalent of a child below the age of 4 years [134]. Rodents can be considered juvenile at P17-21, based on equivalent synapse formation and $\gamma$-aminobutyric acid synthesis than in humans [135]. P35 rodents can be considered equivalent to preadolescent humans [136], as they will have developed $90 \%$ of their adult metabolic process [137] and as their sexual maturity is achieved at P60 [138]. Abbreviations: P: postnatal day; M: postnatal months. 


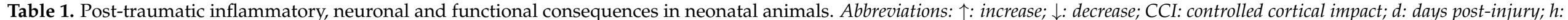
hours post-injury; NC: not compared; NMDA: N-methyl-D-aspartate; P: postnatal days; TBI: traumatic brain injury; WD: weight drop.

\begin{tabular}{|c|c|c|c|c|c|c|c|c|c|}
\hline \multirow{2}{*}{$\begin{array}{l}\text { Animal and } \\
\text { TBI Model }\end{array}$} & \multirow[b]{2}{*}{ Age } & \multirow{2}{*}{$\begin{array}{l}\text { Compa- } \\
\text { rison } \\
\text { Age }\end{array}$} & \multicolumn{6}{|c|}{ Main Highlights } & \multirow[b]{2}{*}{ Reference } \\
\hline & & & Microglia & Astrocytes & $\begin{array}{l}\text { Cytokines and Other } \\
\text { Immune Cells }\end{array}$ & $\begin{array}{l}\text { Brain Lesion and } \\
\text { Neuronal Death }\end{array}$ & $\begin{array}{l}\text { Functional } \\
\text { Deficits }\end{array}$ & $\begin{array}{c}\text { Comparison to } \\
\text { Other Ages }\end{array}$ & \\
\hline $\begin{array}{l}\text { Mice } \\
\text { WD, closed } \\
\text { head, unilateral }\end{array}$ & $\mathrm{P} 3 / 7$ & $\mathrm{P} 10 / 14 / 30$ & & & & $\begin{array}{l}\text { - excitotoxic } \\
\text { degeneration from } 0.5 \\
\text { to } 24 \text { h; peak at } 4 \mathrm{~h} \\
\text { (injury site) } \\
\text { - apoptosis from } 6 \text { to } 24 \\
\text { h (distant site) }\end{array}$ & & $\begin{array}{l}\text { - Brain injury } \\
\text { P3/7 > } \\
\text { P10/14/30 }\end{array}$ & [140] \\
\hline $\begin{array}{l}\text { Mice } \\
\text { WD closed } \\
\text { head, unilateral }\end{array}$ & P7 & $\mathrm{NC}$ & & & & $\begin{array}{l}\text { - neuronal death } \\
\text { expansion from } 0.5 \text { to } 6 \\
\mathrm{~h} \text { (edematous swelling } \\
\text { of dendritic processes } \\
\text { and acute edematous } \\
\text { degeneration of } \\
\text { neuronal cell bodies } \\
\text { with pyknotic changes } \\
\text { of the nuclei) }\end{array}$ & & & [141] \\
\hline $\begin{array}{l}\text { Mice } \\
\text { WD, closed } \\
\text { head, unilateral }\end{array}$ & P7 & $\mathrm{NC}$ & $\begin{array}{l}\text { - activation from } \\
1 \text { to } 21 \mathrm{~d}\end{array}$ & $\begin{array}{l}\text { - activation from } \\
5 \text { to } 21 \mathrm{~d}\end{array}$ & & $\begin{array}{l}\text { - cellular death from } 1 \\
\text { to } 5 \mathrm{~d} \\
\text { - ventriculomegaly at } 21 \\
\text { and } 28 \mathrm{~d}\end{array}$ & & & [142] \\
\hline $\begin{array}{l}\text { Mice } \\
\text { WD, closed } \\
\text { head, unilateral }\end{array}$ & P7 & $\mathrm{NC}$ & & & $\begin{array}{l}\text { - variation in pro- and } \\
\text { anti-inflammatory } \\
\text { cytokines/chemokines } \\
\text { gene expression at } 1 \\
\text { and } 5 \mathrm{~d} \\
\text { - variation in pro- and } \\
\text { anti-inflammatory } \\
\text { immune cells gene } \\
\text { expression at } 1 \text { and } 5 \mathrm{~d}\end{array}$ & $\begin{array}{l}\text { - ventriculomegaly at } 1 \\
\text { and } 5 \mathrm{~d}\end{array}$ & & & [143] \\
\hline
\end{tabular}


Table 1. Cont.

\begin{tabular}{|c|c|c|c|c|c|c|c|c|}
\hline \multirow{2}{*}{$\begin{array}{c}\text { Animal and } \\
\text { TBI Model }\end{array}$} & \multirow[b]{2}{*}{ Age } & \multirow{2}{*}{$\begin{array}{c}\text { Compa- } \\
\text { rison } \\
\text { Age }\end{array}$} & \multicolumn{5}{|c|}{ Main Highlights } & \multirow[b]{2}{*}{ Reference } \\
\hline & & & Astrocytes & $\begin{array}{l}\text { Cytokines and Other } \\
\text { Immune Cells }\end{array}$ & $\begin{array}{l}\text { Brain Lesion and } \\
\text { Neuronal Death }\end{array}$ & $\begin{array}{l}\text { Functional } \\
\text { Deficits }\end{array}$ & $\begin{array}{c}\text { Comparison to } \\
\text { Other Ages }\end{array}$ & \\
\hline $\begin{array}{l}\text { Mice } \\
\text { WD, closed } \\
\text { head, unilateral }\end{array}$ & P7 & $\mathrm{NC}$ & $\begin{array}{l}\text { - activation at } 1 \\
\mathrm{~d} \\
\text { - predominant } \\
\text { repara- } \\
\text { tory/regenerative } \\
\text { or immunomod- } \\
\text { ulatory } \\
\text { macrophage/microglia } \\
\text { phenotype }\end{array}$ & $\begin{array}{l}\text { - } \uparrow \text { pro and } \\
\text { anti-inflammatory } \\
\text { cytokines expression } \\
\text { from } 1 \text { to } 5 \mathrm{~d}(<\text { to adult) } \\
\text { - microglia and } \\
\text { macrophages depletion } \\
=\text { transient } \downarrow \\
\text { pro-inflammatory } \\
\text { cytokines }\end{array}$ & $\begin{array}{l}\text { - thalamus, } \\
\text { hippocampus and } \\
\text { cortex tissue injury at } 1 \\
\mathrm{~d} \\
\text { - ventriculomegaly at } 1 \\
\mathrm{~d}-\text { microglia and } \\
\text { macrophages depletion } \\
=\downarrow \text { neuronal death and } \\
\text { ventriculomegaly at } 1 \mathrm{~d}\end{array}$ & & & [144] \\
\hline $\begin{array}{l}\text { Mice } \\
\text { WD, closed } \\
\text { head, unilateral }\end{array}$ & P7 & $\mathrm{NC}$ & $\begin{array}{l}\text { - activation from } \\
0.5 \text { to } 5 \mathrm{~d}\end{array}$ & & $\begin{array}{l}\text { - excitotoxic } \\
\text { degeneration at } 1 \mathrm{~d}\end{array}$ & & & [139] \\
\hline $\begin{array}{l}\text { Mice } \\
\text { WD, closed } \\
\text { head, unilateral }\end{array}$ & P7 & $\mathrm{NC}$ & & & $\begin{array}{l}-\uparrow \text { neuronal } \\
\text { mitochondrial activity } \\
\text { and size at } 1 \mathrm{~d} \\
-\downarrow 20 \% \text { in sensorimotor } \\
\text { cortical thickness at } 30 \\
\text { d- Neuronal death still } \\
\text { observed at } 23 \mathrm{~d}\end{array}$ & & & [145] \\
\hline $\begin{array}{l}\text { Rats } \\
\text { WD, closed } \\
\text { head, unilateral }\end{array}$ & P7 & $\mathrm{NC}$ & & & & $\begin{array}{l}\text { - Neuronal } \\
\text { death at } 125 \mathrm{~d} \\
\text { (hippocampus) } \\
\text { - Anxiety and } \\
\text { spatial memory } \\
\text { deficits at } 125 \mathrm{~d} \\
\text { - NMDA } \\
\text { antagonist } \\
\text { improves } \\
\text { morphological, } \\
\text { histopathologi- } \\
\text { cal, } \\
\text { neurochemical } \\
\text { and functional } \\
\text { effects of brain } \\
\text { injury at } 125 \mathrm{~d}\end{array}$ & & [146] \\
\hline
\end{tabular}


Table 1. Cont.

\begin{tabular}{|c|c|c|c|c|c|c|c|c|c|}
\hline \multirow{2}{*}{$\begin{array}{l}\text { Animal and } \\
\text { TBI Model }\end{array}$} & \multirow[b]{2}{*}{ Age } & \multirow{2}{*}{$\begin{array}{l}\text { Compa- } \\
\text { rison } \\
\text { Age }\end{array}$} & \multicolumn{6}{|c|}{ Main Highlights } & \multirow[b]{2}{*}{ Reference } \\
\hline & & & Microglia & Astrocytes & $\begin{array}{l}\text { Cytokines and Other } \\
\text { Immune Cells }\end{array}$ & $\begin{array}{l}\text { Brain Lesion and } \\
\text { Neuronal Death }\end{array}$ & $\begin{array}{l}\text { Functional } \\
\text { Deficits }\end{array}$ & $\begin{array}{c}\text { Comparison to } \\
\text { Other Ages }\end{array}$ & \\
\hline $\begin{array}{l}\text { Rats } \\
\text { WD, closed } \\
\text { head, unilateral }\end{array}$ & $\mathrm{P} 3 / 7$ & $\mathrm{P} 14 / 30$ & & & & $\begin{array}{l}\text { - cell death from } 6 \mathrm{~h} \text { to } 5 \\
\mathrm{~d} \text { (peak at } 24 \mathrm{~h})\end{array}$ & & $\begin{array}{l}\text { - apoptosis } \\
\text { P3/P7 > P14/30 }\end{array}$ & [147] \\
\hline $\begin{array}{l}\text { Rats } \\
\text { CCI, closed } \\
\text { head, unilateral }\end{array}$ & P11 & $\mathrm{NC}$ & & & & $\begin{array}{l}-\uparrow \text { intrinsic excitability } \\
\text { and frequency of } \\
\text { spontaneous excitatory } \\
\text { post-synaptic currents } \\
\text { at } 28 \mathrm{~d} \\
-\downarrow \text { frequency of } \\
\text { spontaneous inhibitory } \\
\text { post-synaptic currents } \\
\text { at } 28 \mathrm{~d}\end{array}$ & $\begin{array}{l}\text { - cognitive } \\
\text { deficits at } 28 \mathrm{~d}\end{array}$ & & [148] \\
\hline $\begin{array}{l}\text { Rats } \\
\text { CCI, closed } \\
\text { head, unilateral }\end{array}$ & P11 & P17 & & & & & & $\begin{array}{l}\text { - glial activation } \\
\text { in P11, not in } \\
\text { P17 at } 3 \mathrm{~d} \text { - brain } \\
\text { atrophy and } \\
\text { ventricu- } \\
\text { lomegaly P11 > } \\
\text { P17 at } 14 \text { and } 28 \\
\text { d } \\
\text { - acquisition and } \\
\text { retention } \\
\text { deficits P11 > } \\
\text { P17 at } 28 \mathrm{~d}\end{array}$ & [149] \\
\hline $\begin{array}{l}\text { Rats } \\
\text { CCI, closed } \\
\text { head, unilateral }\end{array}$ & P11 & $\mathrm{NC}$ & $\begin{array}{l}\text { - activation at } 3, \\
15 \text { and } 35 \mathrm{~d} \\
\text { (ipsilateral } \\
\text { cortex) }\end{array}$ & & & $\begin{array}{l}- \text { microglial depletion }= \\
\uparrow \text { neurodegeneration at } \\
3 \mathrm{~d}\end{array}$ & $\begin{array}{l}\text { - microglial } \\
\text { depletion = no } \\
\text { spatial learning } \\
\text { deficits at } 28 \mathrm{~d}\end{array}$ & & [150] \\
\hline $\begin{array}{l}\text { Rats } \\
\text { CCI, closed } \\
\text { head, unilateral }\end{array}$ & P11 & NC & & & & & $\begin{array}{l}\text { - social } \\
\text { recognition } \\
\text { deficits, but } \\
\text { intact sociability } \\
\text { at } 28 \text { and } 56 \mathrm{~d} \\
\text { - no memory } \\
\text { deficit at } 28 \text { and } \\
56 \mathrm{~d}\end{array}$ & & [151] \\
\hline
\end{tabular}




\subsubsection{Post-Traumatic Inflammatory Consequences}

The published data on the consequences of post-traumatic inflammatory on neonatal animals are summarized in Table 1.

Glial cells

Microglial activation is detected from $12 \mathrm{~h}$ post injury (hpi), peaks at $36-48 \mathrm{hpi}$, starts to decrease after 5 days post-injury (dpi) and is still present up to $35 \mathrm{dpi}[139,142,144,145,150]$. Isolated microglia and macrophages have only moderate changes in gene expression and express more markers of repair/regeneration and their immunomodulatory phenotypes [144].

Only one study reported an astrogliosis in neonatal animals, from 5 to $21 \mathrm{dpi}$ [142]. According to the emerging role of astrocytes in microglial activation, this study also highlights the great need for more comprehensive studies on these cells.

Cytokines' expression

A wide variation in cytokines' and chemokines' expression occurs from 1 to 5 dpi after TBI in neonates $[143,144]$. The pro-inflammatory/cytotoxic phenotype markers IL-1 $\beta$ and CCL3 show the greatest and most persistent increases in expression over time ( $>5$ fold) in injured hemisphere. The anti-inflammatory or reparatory/regenerative cytokine IL-4 and the immunomodulatory cytokine IL-10 are also increased at 6, 14 and 24 hpi in the ipsilateral hemisphere. TNF $\alpha$ and IL-12 are the only markers that do not increase at these time points [144].

\subsubsection{Post-Traumatic Neuronal, Tissue and Functional Consequences}

The published data on the post-traumatic neuronal, tissue and functional consequences in neonatal animals are summarized in Table 1.

Neuronal death

Neuronal mitochondrial activity and size increase early after TBI [145]. Neuronal death appears during hours following TBI [141] and is still present at 125 dpi [146]. Early neuronal death, from 0.5 to $24 \mathrm{hpi}$, is due to an excitotoxic mechanism and remains localized to the site of impact [140]. This sensibility to excitotoxic mechanisms might be explained by the poor antioxidant capacities of immature brains [139]. Late neuronal death is due to an apoptotic mechanism that begins at $6 \mathrm{hpi}$ and persists for $5 \mathrm{dpi}$. Secondary apoptotic damages affect sites distant from the impact and appear to be more severe than primary excitotoxic damage [140,142,143,147,152].

Lesion size

Neonatal TBI induces tissue injuries in thalamus and hippocampus [144]; ventriculomegaly from 1 to $21 \mathrm{dpi}$ [142-144] and atrophy of the sensorimotor cortex at $23 \mathrm{dpi}$ [145].

Functional deficits

Few studies have examined the impacts of neonatal TBI in terms of functional deficits. Neonatal TBI induces cognitive deficits in adolescents, at $28 \mathrm{dpi}$, through an impairment in novel object recognition memory [151] along with an increase in the time spent in the open arms of the elevated-plus maze, suggestive of risk-taking behavior [148]. These functional deficits are still present in adulthood [146,151].

\subsubsection{Comparison with Other Ages}

To our knowledge, only three studies compared the consequences of TBI between neonates and older animals (Table 1), showing different consequences in terms of neuroinflammation, neuronal death and functional deficits in the neonates as compared with the adolescent/juvenile group.

Neonatal TBI induces a more important glial activation than juvenile/adolescent TBI [149]. Neonatal animals show an exacerbated neuronal loss and cortical and white matter atrophy following a TBI as compared with adolescent/juvenile animals. In older animals, damage remains limited to the impact site $[140,147]$. Neonatal animals also have more important acquisition deficits compared with adolescents/juveniles, suggesting that age-at-injury is a significant determinant of post-traumatic cognitive deficits [149]. 


\subsubsection{Anti-Inflammatory and Neuroprotective Therapeutic Strategies}

One study tested the effect of minocycline, a second-generation tetracycline antibiotic with anti-inflammatory properties, in a neonatal TBI model [144]. The inhibition of microglial activation by minocycline [153] reduced injury severity at 1 day post-injury, reducing ventricular dilation and cell death. However, minocycline appears to have been only transiently neuroprotective in this model since it had no effect on injury severity at 5 days. Thus, the authors state that, unlike in adults, the role of activated microglia in injury mechanisms following TBI in the immature brain may not be only negative [144].

Another study used cromoglycate, an inhibitor of mast cells' degranulation [154], in a neonatal TBI model [143]. Cromoglycate effectively decreased microglial activation markers. However, it did not reduce TBI-induced ventricular dilation, apoptosis or microglial number. This differs from the effects observed by the inhibition of mast cells in adult TBI [155]. Thus, the role of mast cells in TBI during development seems to be limited and not a viable target for therapies of TBI [143].

The findings of these only two studies that evaluated the effect of the administration of anti-inflammatory agents following a TBI in immature brain highlight the need for further specific therapeutic approach of preventing the consequences of TBI on newborns.

\subsubsection{Conclusions}

Very few studies show interest in the consequences, even in the short term, of TBI in neonates. Especially, almost no studies compared the effect of TBI between neonates and older animals. This is mostly due to the impossibility of transposing the exact same injury model (localization and severity) from neonates to adults because of important differences in overall head, brain and skull anatomy. Thus, further works are needed to investigate mid- and long-term consequences, both on WMI and on neurobehavioral deficits, to explore the remote and persisting effects of TBI.

Nevertheless, these few studies indicate that neonates' reaction to TBI differs from adults. Immature brain immune cells adopt a predominant anti-inflammatory and immunomodulatory phenotype following a TBI, which could explain their overall lower increase in cytokines expression compared with adult brains [144]. Additionally, unlike in adult TBI, the inhibition or depletion of microglia and macrophages is only transiently neuroprotective, as it reduces the lesion volume only at short term [144]. In the same way, mastocyte inhibition aggravates lesions in neonatal TBI, while appearing neuroprotective in adult TBI [143].

The poor antioxidant capacities of the immature brain make it more sensitive to excitotoxic mechanisms and aggravate post-TBI neuronal death [140,147]. Moreover, TBI in immature brains induces changes in the proteins involved in neuronal development (neuronal migration as well as axonal and dendritic growth and guidance) [139], suggesting long term functional deficits that should be evaluated.

Finally, the scarce comparison of the consequences of TBI between different ages has nonetheless showed that neurobehavioral deficits decrease with brain maturity [149].

These studies highlight the difference in the consequences TBI for an immature brain compared with a mature one and suggest more severe consequences of TBI in the immature brain. They confirm the need for a specific approach for developing brain in the consequences of TBI.

\subsection{Juvenile and Adolescent}

Increasingly, studies are exploring the consequences of TBI in juvenile and adolescent populations, but very few, and very recently, show interest in neuroinflammation (Tables 2 and 3). There is no precise definition of juvenile and adolescent ages for rodents and no guidelines for determining interspecies age equivalents. However, P12 and P13 rodents are considered equivalent to human newborns, based on synapse formation and $\gamma$-aminobutyric acid synthesis [135], and the literature considers juvenile rodent as P17-21. Additionally, the age of P17, in rats, is a critical myelination period, as it marks the peak of 
myelin basic protein (MBP) synthesis in the developing rat brain [156,157]. P35 rodents can be considered equivalent to preadolescent humans [136], as they have developed $90 \%$ of their adult metabolic process [137] and will have achieved sexual maturity at P60 [138] (Figure 1).

Yet, in this review, we considered literature's qualifications for categorizing ages of juvenility and adolescence, which corresponded, in the following studies, with P17-P21 animals as juvenile and P35-P42 animals as adolescent. 


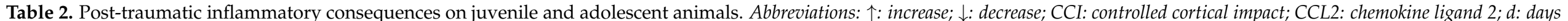

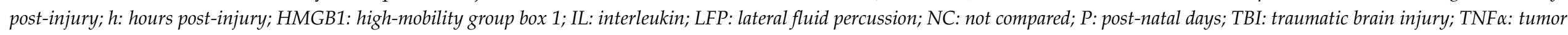
necrosis factor $\alpha ; W$ : post-natal weeks; WD: weight drop.

\begin{tabular}{|c|c|c|c|c|c|c|c|}
\hline \multirow{2}{*}{$\begin{array}{c}\text { Animal and TBI } \\
\text { Model }\end{array}$} & \multirow[b]{2}{*}{ Age } & \multirow{2}{*}{$\begin{array}{l}\text { Compa- } \\
\text { rison } \\
\text { Age }\end{array}$} & \multicolumn{3}{|c|}{ Main Highlights } & \multirow[b]{2}{*}{$\begin{array}{c}\text { Comparison to Other } \\
\text { Ages }\end{array}$} & \multirow[b]{2}{*}{ Reference } \\
\hline & & & Microglia & Astrocytes & $\begin{array}{l}\text { Cytokines and Other } \\
\text { Immune Cells }\end{array}$ & & \\
\hline $\begin{array}{l}\text { Mice } \\
\text { CCI, closed head, } \\
\text { unilateral }\end{array}$ & P17 & $\mathrm{NC}$ & & $\begin{array}{l}\text { - activation } 1,7 \text { and } 30 \mathrm{~d} \\
\text { (corpus callosum) }\end{array}$ & & & [158] \\
\hline $\begin{array}{l}\text { Mice } \\
\text { CCI, closed head, } \\
\text { unilateral }\end{array}$ & P17 & $\mathrm{NC}$ & & $\begin{array}{l}\text { - hypertrophic morphology } \\
\text { and extension of processes } \\
\text { from } 1 \text { to } 30 \mathrm{~d} \text { (ipsilateral } \\
\text { cortex first, then spread in } \\
\text { remote regions) } \\
\text { - proliferation from } 1 \text { to } 30 \\
\mathrm{~d} \text { (ipsilateral cortex first, } \\
\text { then spread in remote } \\
\text { regions) }\end{array}$ & & & [159] \\
\hline $\begin{array}{l}\text { Mice } \\
\text { CCI, closed head, } \\
\text { unilateral }\end{array}$ & P21 & $\mathrm{NC}$ & - activation at $14 \mathrm{~d}$ & & & & [160] \\
\hline $\begin{array}{l}\text { Mice } \\
\text { CCI, open skull, } \\
\text { unilateral }\end{array}$ & P21 & W8/10 & & & & $\begin{array}{l}\text { - microglial and astrocyte } \\
\text { activation } \uparrow \text { earlier and } \\
\text { higher in P21 } \\
\text { - } \uparrow \text { in HMGB1 in P21 } \\
\text { serum, not in adult } \\
\text { - cellular inflammatory } \\
\text { response varies with age }\end{array}$ & [161] \\
\hline $\begin{array}{l}\text { Mice } \\
\text { CCI, open skull, } \\
\text { unilateral }\end{array}$ & P21 & $\mathrm{NC}$ & $\begin{array}{l}\text { - activation from } 3 \text { to } 35 \mathrm{~d} \\
\text { (corpus callosum) }\end{array}$ & $\begin{array}{l}\text { - activation from } 3 \text { to } 35 \mathrm{~d} \\
\text { (corpus callosum) }\end{array}$ & & & [162] \\
\hline $\begin{array}{l}\text { Mice } \\
\text { CCI, open skull, } \\
\text { unilateral }\end{array}$ & $\mathrm{P} 21$ & $\mathrm{NC}$ & $\begin{array}{l}\text { - no } \uparrow \text { at } 1 \text { and } 4 \mathrm{~d} \\
\text { - activation at } 8 \mathrm{~d} \\
\text { (ipsilateral cortex) }\end{array}$ & $\begin{array}{l}\text { - activation at } 8 \mathrm{~d} \\
\text { (hippocampus) }\end{array}$ & $\begin{array}{l}-\uparrow \text { neutrophils at } 4 \mathrm{~d} \\
-\uparrow \text { lymphocytes } \mathrm{T} \text { helper at } \\
4 \mathrm{~d}\end{array}$ & & [163] \\
\hline $\begin{array}{l}\text { Mice } \\
\text { CCI, closed head, } \\
\text { unilateral }\end{array}$ & P35 & $\mathrm{NC}$ & $\begin{array}{l}\text { - activation at } 1 \mathrm{~d} \\
\text { - isoflurane } \downarrow \text { activation at } \\
1 \mathrm{~d}\end{array}$ & $\begin{array}{l}\text { - no activation at } 1 \mathrm{~d} \\
\text { (corpus callosum) }\end{array}$ & & & [164] \\
\hline
\end{tabular}


Table 2. Cont

\begin{tabular}{|c|c|c|c|c|c|c|c|}
\hline \multirow{2}{*}{$\begin{array}{c}\text { Animal and TBI } \\
\text { Model }\end{array}$} & \multirow[b]{2}{*}{ Age } & \multirow{2}{*}{$\begin{array}{l}\text { Compa- } \\
\text { rison } \\
\text { Age }\end{array}$} & \multicolumn{3}{|c|}{ Main Highlights } & \multirow[b]{2}{*}{$\begin{array}{c}\text { Comparison to Other } \\
\text { Ages }\end{array}$} & \multirow[b]{2}{*}{ Reference } \\
\hline & & & Microglia & Astrocytes & $\begin{array}{l}\text { Cytokines and Other } \\
\text { Immune Cells }\end{array}$ & & \\
\hline $\begin{array}{l}\text { Mice } \\
\text { CCI, open skull, } \\
\text { unilateral }\end{array}$ & P42 & $\mathrm{NC}$ & $\begin{array}{l}\text { - activation from } 1 \text { to } 14 \mathrm{~d} \\
\text { (cortex and nucleus } \\
\text { accumbens) } \\
\text { - dexamethasone } \downarrow \\
\text { activation }\end{array}$ & $\begin{array}{l}\text { - activation from } 1 \text { to } 14 \mathrm{~d} \\
\text { (cortex and nucleus } \\
\text { accumbens) } \\
\text { - dexamethasone } \downarrow \\
\text { activation }\end{array}$ & $\begin{array}{l}\text { - dexamethasone } \downarrow \\
\text { peripheral immune cell } \\
\text { recruitment }\end{array}$ & & [165] \\
\hline $\begin{array}{l}\text { Mice } \\
\text { CCI, open skull, } \\
\text { unilateral }\end{array}$ & P42 & $\mathrm{NC}$ & $\begin{array}{l}\text { - activation at } 1 \text { and } 30 \mathrm{~d} \\
\text { (cortex and nucleus } \\
\text { accumbens) }\end{array}$ & $\begin{array}{l}\text { - activation at } 1 \text { and } 30 \mathrm{~d} \\
\text { (cortex and nucleus } \\
\text { accumbens) }\end{array}$ & $\begin{array}{l}\text { - } \uparrow \text { inflammatory markers } \\
\text { at } 1 \text { and } 14 \mathrm{~d} \\
\text { - pro-inflammatory } \\
\text { cytokines predominate at } \\
14 \mathrm{~d}\end{array}$ & & [166] \\
\hline $\begin{array}{l}\text { Mice } \\
\text { CCI, open skull, } \\
\text { unilateral }\end{array}$ & P42 & $\mathrm{NC}$ & $\begin{array}{l}\text { - activation at } 7 \text { and } 30 \mathrm{~d} \\
\text { (optical tract) }\end{array}$ & $\begin{array}{l}\text { - activation at } 7 \text { and } 30 \mathrm{~d} \\
\text { (optical tract) }\end{array}$ & & & [167] \\
\hline $\begin{array}{l}\text { Mice } \\
\text { CCI, open skull, } \\
\text { unilateral }\end{array}$ & $\mathrm{P} 42$ & W8 & & & & $\begin{array}{l}\text { - variation in infiltrated } \\
\text { immune cell profile and } \uparrow \\
\text { microglial phagocytosis of } \\
\text { neuronal proteins in P42 } \\
\text { - duration of microglial } \\
\text { activation and } \\
\text { phagocytosis and } \\
\text { monocytes infiltration P42 } \\
\text { > W8 }\end{array}$ & [168] \\
\hline $\begin{array}{l}\text { Rabbits } \\
\text { CCI, open skull, } \\
\text { unilateral }\end{array}$ & P5/7 & $\mathrm{NC}$ & $\begin{array}{l}\text { - activation at } 7 \mathrm{~d} \text { (ipsi- } \\
\text { and contralateral white } \\
\text { matter tracts) }\end{array}$ & & & & [131] \\
\hline
\end{tabular}


Table 2. Cont.

\begin{tabular}{|c|c|c|c|c|c|c|c|}
\hline \multirow{2}{*}{$\begin{array}{c}\text { Animal and TBI } \\
\text { Model }\end{array}$} & \multirow[b]{2}{*}{ Age } & \multirow{2}{*}{$\begin{array}{l}\text { Compa- } \\
\text { rison } \\
\text { Age }\end{array}$} & \multicolumn{3}{|c|}{ Main Highlights } & \multirow[b]{2}{*}{$\begin{array}{c}\text { Comparison to Other } \\
\text { Ages }\end{array}$} & \multirow[b]{2}{*}{ Reference } \\
\hline & & & Microglia & Astrocytes & $\begin{array}{l}\text { Cytokines and Other } \\
\text { Immune Cells }\end{array}$ & & \\
\hline $\begin{array}{l}\text { Rabbits } \\
\text { CCI, open skull, } \\
\text { unilateral }\end{array}$ & $\mathrm{P} 5 / 7$ & $\mathrm{NC}$ & & & $\begin{array}{l}\text { - } \uparrow \text { pro- and } \\
\text { anti-inflammatory } \\
\text { cytokine from } 6 \mathrm{~h} \text { to } 21 \mathrm{~d} \\
\text { (peak at } \neq \text { time points) } \\
\text { - pro-inflammatory } \\
\text { cytokines } \uparrow \text { within the } 6 \mathrm{~h} \text {, } \\
\text { peak between } 6 \mathrm{~h} \text { and } 3 \mathrm{~d} \text {, } \\
\downarrow \text { at } 7 \mathrm{~d} \text { and stay elevated } \\
\text { at } 21 \mathrm{~d} \\
\text { - anti-inflammatory } \\
\text { cytokines peaked at } 6 \mathrm{~h} \\
\text { and then } \downarrow \text { quickly }\end{array}$ & & [169] \\
\hline $\begin{array}{l}\text { Rats } \\
\text { WD, closed head, } \\
\text { centered }\end{array}$ & P17 & $\mathrm{NC}$ & & $\begin{array}{l}\text { - activation from } 1 \text { to } 7 \mathrm{~d} \text {, } \\
\text { peak at } 3 \mathrm{~d} \text { (hippocampus, } \\
\text { white matter tracts, corpus } \\
\text { callosum, brainstem and } \\
\text { forebrain) }\end{array}$ & & & [170] \\
\hline $\begin{array}{l}\text { Rats } \\
\text { CCI, closed head, } \\
\text { centered }\end{array}$ & P17 & $\mathrm{NC}$ & & $\begin{array}{l}\text { - activation from } 8 \mathrm{~d} \text { to } 18 \\
\mathrm{~d}\end{array}$ & & & [171] \\
\hline $\begin{array}{l}\text { Rats } \\
\text { CCI, open skull, } \\
\text { unilateral }\end{array}$ & P17 & $\mathrm{NC}$ & & $\begin{array}{l}-\uparrow g f a p \text { expression at } 1 \mathrm{~d} \\
\text { and } 4 \mathrm{~d}\end{array}$ & $\begin{array}{l}\text { - } \uparrow c c l 2 \text { expression at } 1 \mathrm{~d} \\
\text { and } 4 \mathrm{~d}\end{array}$ & & [172] \\
\hline $\begin{array}{l}\text { Rats } \\
\text { CCI, open skull, } \\
\text { unilateral }\end{array}$ & P17 & $\mathrm{NC}$ & & & $\begin{array}{l}-\uparrow \mathrm{TNF} \alpha, \mathrm{IL}-1 \beta, \mathrm{CCL} 2, \\
\text { and IL- } 6 \text { at } 1 \text { and } 2 \mathrm{~d}\end{array}$ & & [173] \\
\hline $\begin{array}{l}\text { Rats } \\
\text { CCI, open skull, } \\
\text { unilateral }\end{array}$ & P17 & $\mathrm{NC}$ & $\begin{array}{l}\text { - activation at } 7 \mathrm{~d} \\
\text { (ipsilateral cortex, } \\
\text { hippocampus and } \\
\text { thalamus) } \\
\text { - minocycline } \downarrow \text { activation }\end{array}$ & & & & [174] \\
\hline $\begin{array}{l}\text { Rats } \\
\text { CCI, open skull, } \\
\text { unilateral }\end{array}$ & P17 & $\mathrm{NC}$ & $\begin{array}{l}\text { - activation at } 3 \text { and } 7 \mathrm{~d} \\
\text { (cortex and hippocampus) } \\
\text { - docosahexaenoic acid } \downarrow \\
\text { activation }\end{array}$ & $\begin{array}{l}\text { - activation at } 3 \text { and } 7 \mathrm{~d} \\
\text { (cortex) } \\
\text { - docosahexaenoic acid } \downarrow \\
\text { activation }\end{array}$ & & & [175] \\
\hline
\end{tabular}


Table 2. Cont.

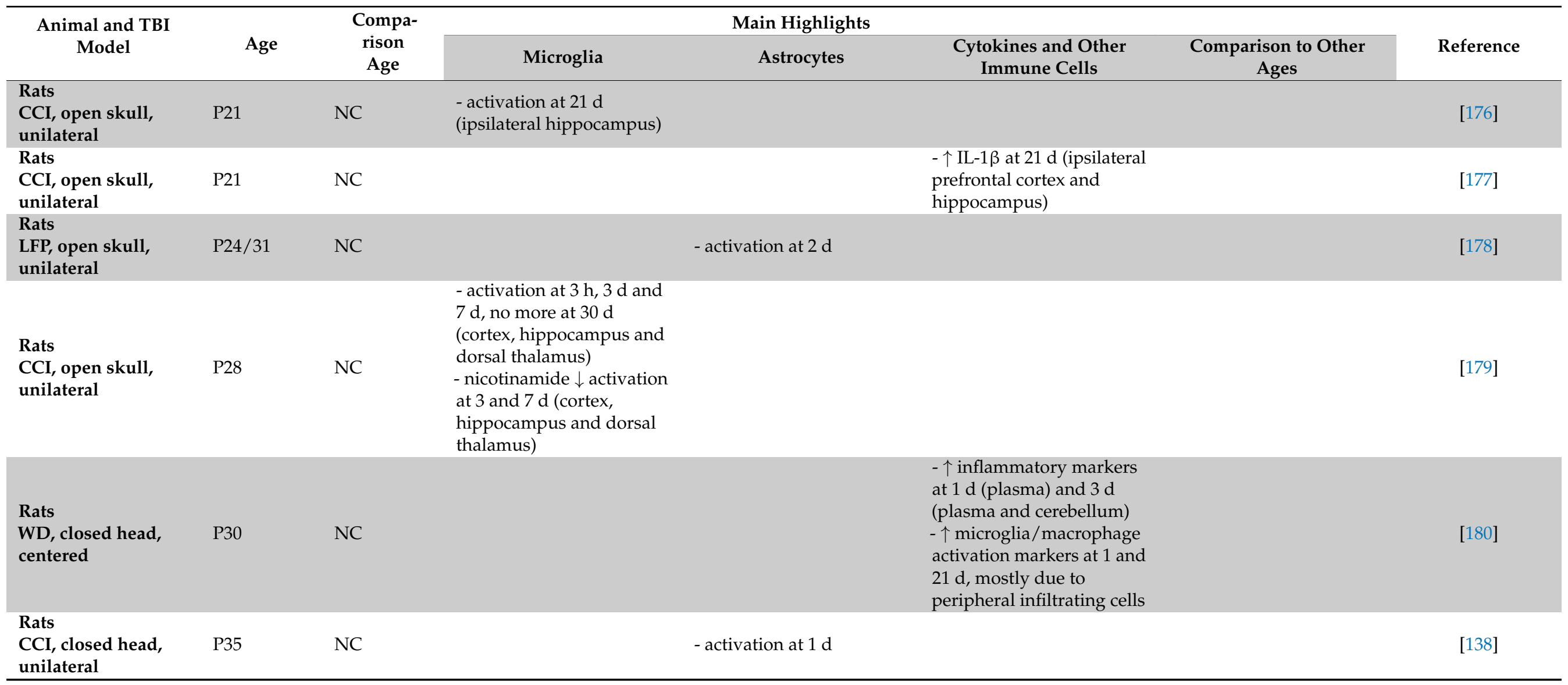




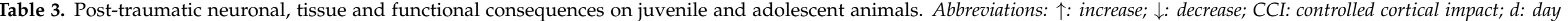

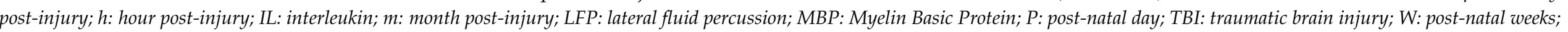
WD: weight drop.

\begin{tabular}{|c|c|c|c|c|c|c|}
\hline \multirow{2}{*}{$\begin{array}{c}\text { Animal and TBI } \\
\text { Model }\end{array}$} & \multirow[b]{2}{*}{ Age } & \multirow{2}{*}{$\begin{array}{c}\text { Compa-rison } \\
\text { Age }\end{array}$} & \multicolumn{3}{|c|}{ Main Highlights } & \multirow[b]{2}{*}{ Reference } \\
\hline & & & Neuronal Death and Brain Lesion & Functional Deficits & Comparison to Other Ages & \\
\hline $\begin{array}{l}\text { Mice } \\
\text { CCI, closed head, } \\
\text { unilateral }\end{array}$ & P17 & NC & $\begin{array}{l}\text { - no major axonal disruption at } 1 \mathrm{~d} \\
\text { - white matter alteration at } 7 \mathrm{~d} \\
\text { (corpus callosum) }\end{array}$ & $\begin{array}{l}\text { - motor deficits at } 30 \mathrm{~d} \\
\text { - memory deficits at } 30 \mathrm{~d} \\
\text { - anxiety-like behavior at } 30 \mathrm{~d}\end{array}$ & & [158] \\
\hline $\begin{array}{l}\text { Mice } \\
\text { CCI, open skull, } \\
\text { unilateral }\end{array}$ & P21 & $\mathrm{NC}$ & $\begin{array}{l}\text { - neuronal loss at } 1 \mathrm{~d} \text { (ipsilateral } \\
\text { subcortical white matter), } 3 \mathrm{~d} \\
\text { (ipsilateral external capsule, caudate } \\
\text { putamen and contralateral } \\
\text { subcortical white matter) and } 7 \mathrm{~d} \\
\text { (internal capsule, pyramidal tracts, } \\
\text { and cerebellar peduncles) } \\
\text { - neuronal loss at } 7 \mathrm{~d} \text { is in regions } \\
\text { where microglia/macrophage } \\
\text { activation is more prominent } \\
\text { (ipsilateral cortex, hippocampus, } \\
\text { and thalamus) }\end{array}$ & & & [181] \\
\hline $\begin{array}{l}\text { Mice } \\
\text { CCI, open skull, } \\
\text { unilateral }\end{array}$ & P21 & $\mathrm{NC}$ & $\begin{array}{l}\text { - } \downarrow \text { oligodendrocyte progenitor cells } \\
\text { and post-mitotic oligodendrocytes } \\
\text { at } 35 \mathrm{~d} \text { (corpus callosum) } \\
\text { - myelin fragmentation at } 35 \mathrm{~d} \\
\text { (external capsule) } \\
\text { - tissue loss at } 35 \mathrm{~d} \text { (perilesional } \\
\text { regions) }\end{array}$ & $\begin{array}{l}\text { - anxiety-like behavior and } \\
\text { social memory deficits at } 35 \mathrm{~d} \\
\text { - no locomotor deficits at } 35 \mathrm{~d}\end{array}$ & & [162] \\
\hline $\begin{array}{l}\text { Mice } \\
\text { CCI, open skull, } \\
\text { unilateral }\end{array}$ & P21 & $\mathrm{NC}$ & - tissue loss at $8 \mathrm{~d}$ (cortex) & & & [163] \\
\hline $\begin{array}{l}\text { Mice } \\
\text { CCI, open skull, } \\
\text { unilateral }\end{array}$ & $\mathrm{P} 21 / 25$ & W8/12 & & & $\begin{array}{l}\text { - mortality rate } \mathrm{P} 21>\text { adult } \\
\text { (mostly due to surgical } \\
\text { complications) } \\
\text { - motor performance } \\
\text { impairment } \mathrm{W} 8 / 12>\mathrm{P} 21 \text { but no } \\
\text { other behavioral tests }\end{array}$ & [182] \\
\hline $\begin{array}{l}\text { Mice } \\
\text { CCI, closed head, } \\
\text { unilateral }\end{array}$ & P35 & $\mathrm{NC}$ & - isoflurane $\downarrow$ axonal injury at $1 \mathrm{~d}$ & & & [164] \\
\hline
\end{tabular}


Table 3. Cont

\begin{tabular}{|c|c|c|c|c|c|c|}
\hline \multirow{2}{*}{$\begin{array}{c}\text { Animal and TBI } \\
\text { Model }\end{array}$} & \multirow[b]{2}{*}{ Age } & \multirow{2}{*}{$\begin{array}{c}\text { Compa-rison } \\
\text { Age }\end{array}$} & \multicolumn{3}{|c|}{ Main Highlights } & \multirow[b]{2}{*}{ Reference } \\
\hline & & & Neuronal Death and Brain Lesion & Functional Deficits & Comparison to Other Ages & \\
\hline $\begin{array}{l}\text { Mice } \\
\text { CCI, open skull, } \\
\text { unilateral }\end{array}$ & P42 & $\mathrm{NC}$ & & & $\begin{array}{l}\text { - dexamethasone } \downarrow \text { cognitive } \\
\text { and behavioral deficits }\end{array}$ & [165] \\
\hline $\begin{array}{l}\text { Mice } \\
\text { LFP, open skull, } \\
\text { unilteral }\end{array}$ & P42 & $\mathrm{NC}$ & $\begin{array}{l}\text { - tissue loss and neuronal death at } \\
16 \mathrm{~d}\end{array}$ & $\begin{array}{l}\text { - acquisition deficit at } 9 \text { and } 19 \mathrm{~d} \\
\text { - motor deficit from } 1 \text { to } 16 \mathrm{~d}\end{array}$ & & [183] \\
\hline $\begin{array}{l}\text { Mice } \\
\text { CCI, open skull, } \\
\text { unilateral }\end{array}$ & P42 & NC & $\begin{array}{l}\text { - neuronal loss at } 7 \text { and } 30 \mathrm{~d} \text { (optic } \\
\text { tract) }\end{array}$ & $\begin{array}{l}\text { - optokinetic response and } \\
\text { visual acuity deficit at } 7 \text { and } 30 \mathrm{~d} \\
\text { - no circadian rhythm alteration } \\
\text { at } 7 \text { and } 30 \mathrm{~d}\end{array}$ & & [167] \\
\hline $\begin{array}{l}\text { Mice } \\
\text { CCI, open skull, } \\
\text { unilateral }\end{array}$ & P42 & W8 & & & $\begin{array}{l}\text { - } \uparrow \text { sensitivity to cocaine } \\
\text { rewarding effects in P42 } \\
\text { - no difference in the alteration } \\
\text { of other behaviors } \\
\text { - } \downarrow \text { synaptic arborization } \\
\text { complexity and spine density in } \\
\text { the nucleus accumbens, and } \\
\text { alteration of dopamine } \\
\text { system-related genes expression } \\
\text { P42 > W8 }\end{array}$ & [168] \\
\hline $\begin{array}{l}\text { Mice } \\
\text { WD, closed head, } \\
\text { central }\end{array}$ & P42 & W9 & & & $\begin{array}{l}\text { - hippocampal } \\
\text { neurodegeneration only in } \mathrm{P} 42 \text {, } \\
\text { correlated to microglial } \\
\text { activation (not astrocyte } \\
\text { activation) } \\
\text { - motor deficits recovery at } 16 \mathrm{~d} \\
\text { in P42 = W9 } \\
\text { - memory deficits at 3-4 d and } \\
4-16 \text { d only in P42 } \\
\text { - mortality rate P42 > W9 }\end{array}$ & [184] \\
\hline $\begin{array}{l}\text { Rabbits } \\
\text { CCI, open skull, } \\
\text { unilateral }\end{array}$ & $\mathrm{P} 5 / 7$ & $\mathrm{NC}$ & $\begin{array}{l}\text { - brain lesion at } 3 \text { and } 7 \mathrm{~d} \\
\text { - brain atrophy at } 21 \mathrm{~d} \text { (ipsilateral } \\
\text { hemisphere) }\end{array}$ & - cognitive deficits at 9 and $19 \mathrm{~d}$ & & [131] \\
\hline $\begin{array}{l}\text { Rats } \\
\text { WD, closed head, } \\
\text { centered }\end{array}$ & P17 & $\mathrm{NC}$ & $\begin{array}{l}\text { - axonal injury from } 3 \text { to } 7 \mathrm{~d} \\
\text { correlated with astrogliosis } \\
\text { localization (brainstem and } \\
\text { forebrain) }\end{array}$ & & & [170] \\
\hline
\end{tabular}


Table 3. Cont

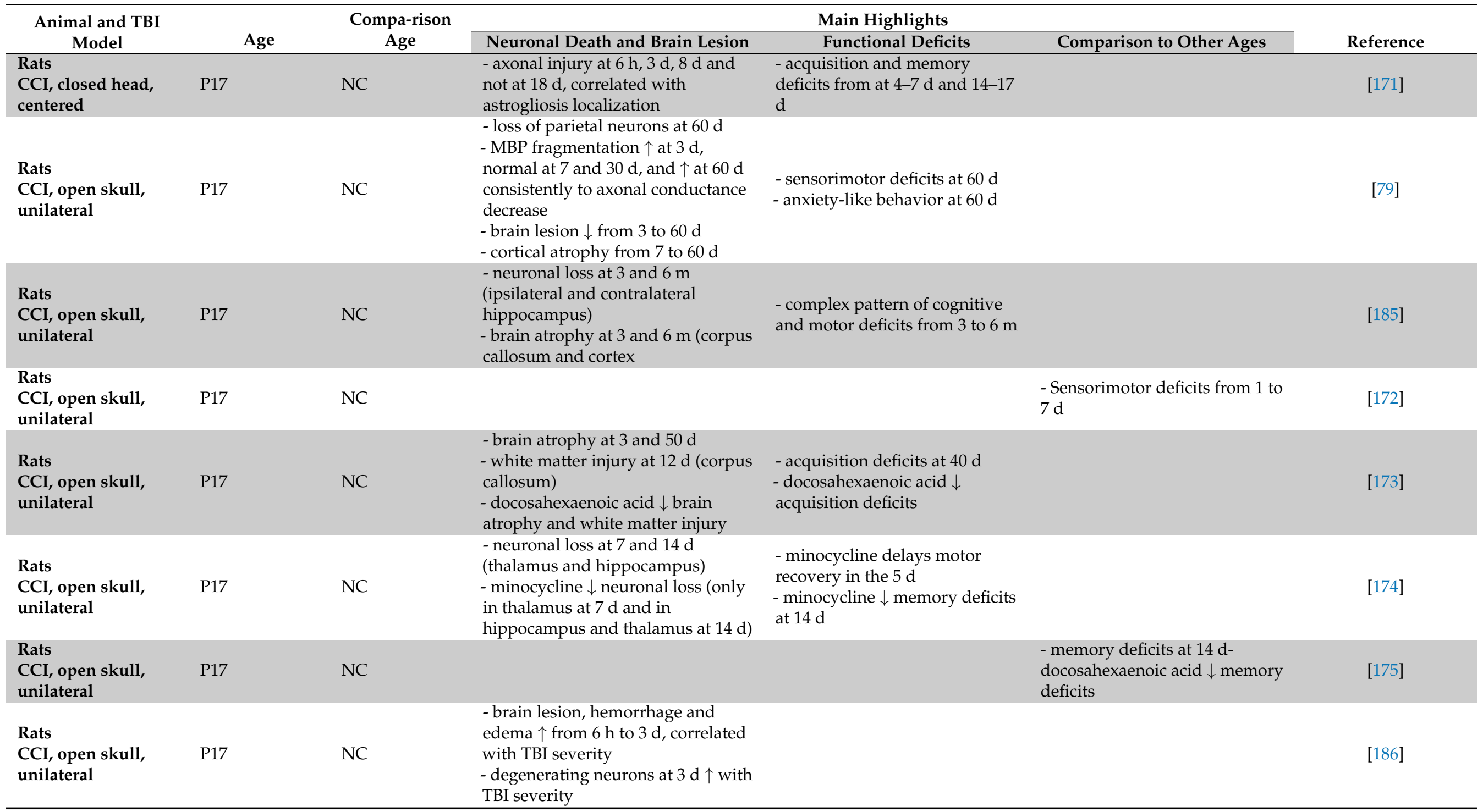


Table 3. Cont

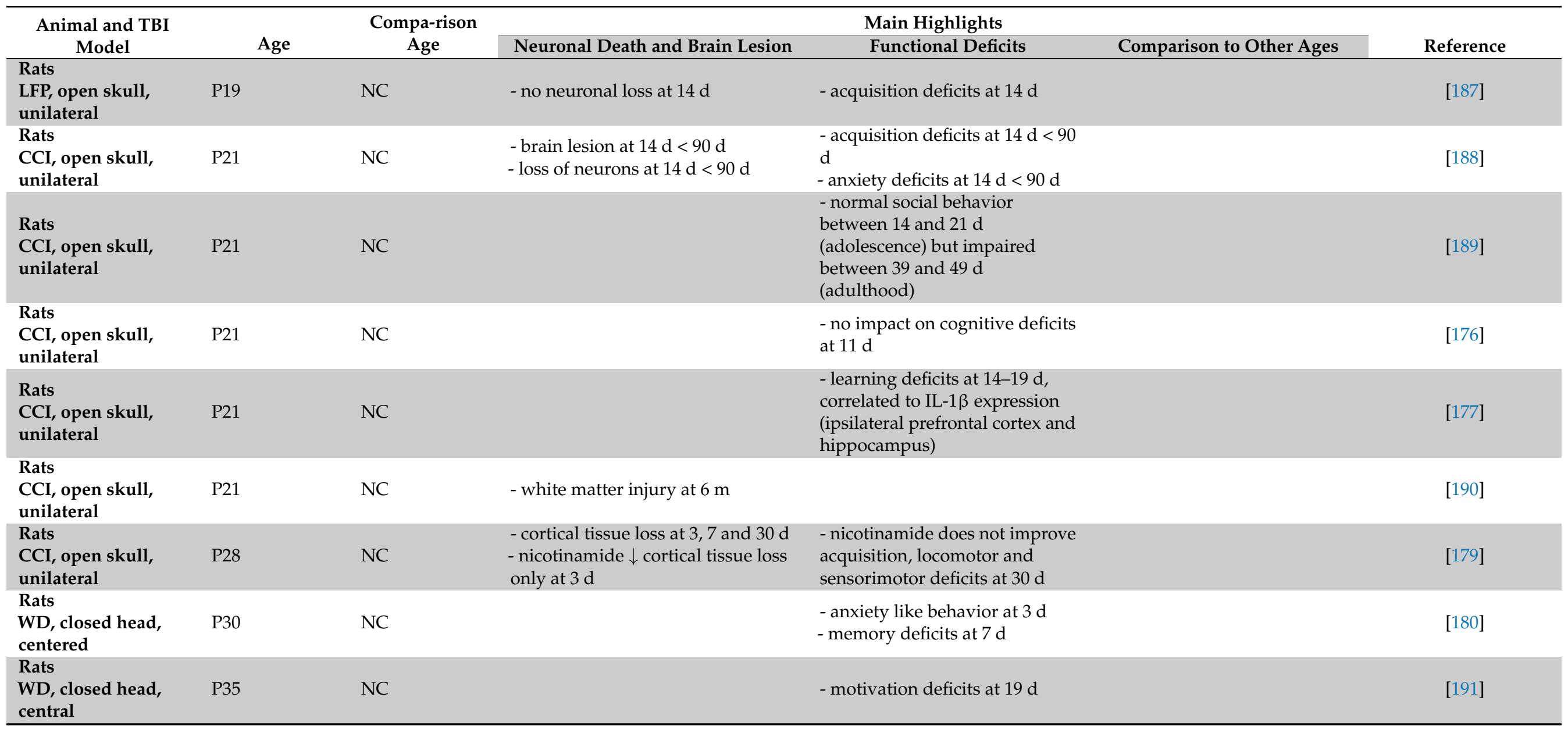




\subsubsection{Post-Traumatic Inflammatory Consequences}

The published data on post-traumatic inflammatory consequences on juvenile and adolescent animals are summarized in Table 2.

Microglia

Microglial activation appears as early as $1 \mathrm{dpi}$ and has been found up to 35 dpi $[160,162-167,176]$. It starts in structures close to the impact and extends to remote regions [166]. In rabbits at $7 \mathrm{dpi}$, microglia are activated in white matter tracts in the ipsilateral and, to a lesser extent, contralateral hemispheres [131].

Astrocytes

Astrocyte activation is absent before $1 \mathrm{dpi}[138,158,165,166,170,171]$. It begins at $1 \mathrm{dpi}$ and lasts until 35 dpi $[138,158,159,162,163,165-167,170,171,175,178]$, starting to spread to remote and contralateral regions from $7 \mathrm{dpi}$ [159]. Astrogliosis is no longer present at 180 dpi [158]. Interestingly, a study reported microglial activation at $1 \mathrm{dpi}$ but not astrocyte activation [164], suggesting that astrocytes do not contribute to microglial activation.

Other immune cells and cytokines expression

In the cerebellum, peripheral macrophages contribute to the inflammatory process at 1 and $21 \mathrm{dpi}$, contrarily to microglia, which are not increased at this time in this region [180].

Cytokine expression is widely modified from 6 hpi to 21 dpi [166,169,172,173,177,180]. Specifically, anti-inflammatory cytokines peak in the hours following the TBI, but decrease rapidly [169]. Pro-inflammatory cytokines peaks later, between $6 \mathrm{hpi}$ and $3 \mathrm{dpi}$, and stay predominant until $21 \mathrm{dpi}[166,169]$. In the plasma, cytokine levels increase between 1 and $3 \mathrm{dpi}$, and return to normal levels at $7 \mathrm{dpi}$ [180]. Overall, cytokines increased expression is correlated to the presence of activated microglia and astrocytes [166]. However, the precise expression patterns of the different cytokines and their relation to the activation of microglia and astrocyte phenotypes has not been studied, yet, in juvenile or adolescent TBI models.

\subsubsection{Post-Traumatic Neuronal, Tissue and Functional Consequences}

The published data on the post-traumatic neuronal, tissue and functional consequences on juvenile and adolescent animals are summarized in Table 3.

Neuronal death

Neuronal death appears from $6 \mathrm{hpi}$ in the cortex [171] and spreads to the thalamus and contralateral hemisphere at $3 \mathrm{dpi}[181]$ and to remote brain areas at $7 \mathrm{dpi}[170,181]$. This neuronal death persists into the long term $[79,158,167,171,183,188]$ and is still visible at $6 \mathrm{mpi}$ [185].

MBP fragmentation appears at $3 \mathrm{dpi}$ [79] and persists until $60 \mathrm{dpi}$ in the white matter tract, consistently, leading to decreased axonal conductance $[79,158,162]$.

The neuronal loss, specifically through traumatic axonal injuries, is correlated in terms of localization to astrogliosis $[170,171]$ and to activated microglia/macrophage [181,184], highlighting the implication of neuroinflammation in the neuronal loss.

Lesion size

This neuronal death leads to brain atrophy and WMI, visible from 7 to 60 dpi $[79,131,158,163,171,185,188,190]$ and even at 6 mpi $[173,185]$.

A magnetic resonance imaging analysis revealed the presence of blood in tissues and edema from 6 hpi to $3 \mathrm{dpi}$, even in mild juvenile TBI, with edema volume correlated to severity [186]. In rabbits, lesion volume increased from $16 \%$ at $3 \mathrm{dpi}$ to $30 \%$ at $7 \mathrm{dpi}$, indicating ongoing secondary injuries at these time points [131].

Functional deficits

Correlated to the temporal evolution of lesion size, adolescent and juvenile animals show functional deficits, such as learning/memory [158,171,177,180,187,188,191], motor $[79,158,172,180,183]$ and anxiety-like behavior deficits $[79,158,162,180,188]$. These deficits appear in the adolescence and last into adulthood [79,158,162,173,189]. Specifically, adolescent TBI increases the sensitivity to the rewarding effects of cocaine in adulthood [168]. A study also reported visual and optokinetic response deficits, correlated to microglia and astrocyte activation in the optical tract [167]. 
In rabbits, TBI resulted in cognitive deficits (T-maze and novel object recognition) at 9 and 19 dpi (P14 and P24) [131].

\subsubsection{Comparison with Young Adult TBI}

Compared with young adult TBI, the immune cell infiltration, microglial activation, and phagocytosis of neuronal proteins is different in adolescent TBI (Table 2). Specifically, compared with young adults:

- microglial activation increases earlier and is stronger, and persist longer in adolescent TBI [161,168];

- $\quad$ astrocyte activation occurs earlier and is stronger in adolescent TBI [161];

- peripheral immune transcriptomic profiles differ in juvenile TBI [192];

- monocytes infiltration persists longer in adolescent TBI [168].

The post-traumatic neurological and functional consequences following adolescent TBI are more important than the consequences following adult TBI (Table 3). Specifically, compared with adults:

- dopamine system-related genes are altered [168];

- synaptic arborization complexity and spine density are reduced in the nucleus accumbens [168];

- functional deficits are similar [182], except for memory deficits, more important in adolescent TBI [184];

- mortality rate is higher following adolescent TBI [182,184].

\subsubsection{Anti-Inflammatory and Neuroprotective Therapeutic Strategies}

Several studies evaluated the effect of anti-inflammatory or neuroprotective strategies in juvenile TBI model.

The anti-inflammatory approaches showed interesting results. The anti-inflammatory properties of docosahexaenoic acid decrease neuroinflammation and neuronal death in adult TBI models [193]. Similarly, in juvenile models, several studies showed that docosahexaenoic acid decreases microglial activation, macrophage infiltration, brain edema, oxidative stress, lesion volume, and short- and long-term neurological deficits following TBI $[172,173,175]$. Similarly, minocycline reduces microglial activation, attenuates neurodegeneration and increases neuronal survival following juvenile TBI [174], as in adult models [194]. Finally, dexamethasone, a steroidal anti-inflammatory molecule that has been shown to both decrease the post-TBI inflammatory response and promote neuronal plasticity, attenuated the cocaine place preference of injured juvenile animals [165].

Neuroprotective therapies are also effective in reducing the consequences of TBI in juvenile animals. The administration of isoflurane results in a decrease in microglial activation, neuronal death and cognitive and sensorimotor deficits [164]. These results are consistent with those found in adults [195]. However, the results of neuroprotective strategies do not seem to be always as effective in juvenile animals as it is in adult animals. Indeed, nicotinamide administration in juvenile TBI decreases microglial activation and neuronal loss [179], but does not reduce the lesion volume nor improve behavioral outcomes, as it does in adults [196]. This highlights the age-dependent nature of the response to pharmacological strategies and the need for more studies evaluating specific anti-inflammatory and neuroprotective approaches in juvenile models.

\subsubsection{Conclusions}

Adolescent and juvenile TBI have been more studied than the two other specific ages of interest in this review. However, only a few have studied the long-term consequences of TBI, or directly compared juvenile or adolescent TBI to adult TBI.

As in adults, adolescent/juvenile TBI induces (1) glial activation and neuroinflammation leading to (2) neuronal death and WMI and to (3) functional deficits. Indeed, the administration of anti-inflammatory substances like dexamethasone, minocycline or docosahexaenoic acid decreases microglial and astrocyte activation $[165,173-175,179]$ and 
peripheral immune cell recruitment [165]. These anti-inflammatory strategies also decrease WMI $[173,174]$ and functional deficits $[165,173-175]$. These elements confirm the implication of neuroinflammation, directly or not, in WMI and functional deficits. However, minocycline did not have any effect on lesion volume, and although it promoted motor recovery, it worsened acquisition impairments [174], suggesting a more complex role of neuroinflammation than being only deleterious.

The few studies that showed interest in the long-term consequences of TBI showed that functional deficits last for months after injury, into adulthood [79,162], especially cognitive deficits $[158,185]$. Mice that sustained TBI during adolescence also showed impaired social behavior [189] and increased sensitivity to the rewarding effects of cocaine in adulthood [168]. It highlights the lifelong consequences of an adolescent TBI. These findings are essential for human research in TBI, and the neurobehavioral consequences thereof should be the subject of further long-term study.

Comparative studies have highlighted different patterns of glial activation and neuroinflammation processed as compared with older animals [161,168,192]. They also reported variable consequences on brain lesion, neurodegeneration and neurobehavioral deficit $[182,184]$. Finally, in a juvenile rat TBI model, nicotinamide did not significantly improve behavioral impairments, conversely to older rat models, suggesting a different pathological pattern between juvenile and older adult TBI [179].

These studies highlight the need of (1) further comparative studies between adolescent or juvenile TBIs and adult TBIs and (2) a specific approach adapted to adolescent/juvenile care in preclinical and clinical research.

\subsection{Aged}

TBI prevalence is high in aged populations and is associated with increased mortality and poorer functional outcomes in older patients. It is known that the microglial activation profile changes in the aged brain [197], but the underlying molecular and cellular mechanisms of secondary injury in the aged brain are still poorly understood, and aged TBI models are underrepresented in the literature [198]. Despite the small number of studies concerning it, they show the advantage to often compare to young adults, aged 3 months. Only rodents have been studied in the preclinical studies on aged animals. Rodents aged 12 to 18 months are assumed to correspond to middle-aged humans, and rodents aged 22 to 24 months are assumed to correspond to aged humans (Figure 1, Tables 4 and 5). 


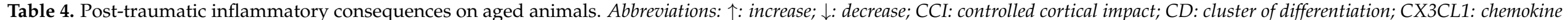

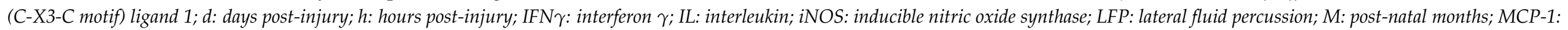
monocyte chemoattractant protein-1; NC: not compared; TBI: traumatic brain injury; TGF $\beta$ : transforming growth factor $\beta$; TNF $\alpha$ : tumor necrosis factor $\alpha$; W: post-natal weeks; YA: young adult.

\begin{tabular}{|c|c|c|c|c|c|c|}
\hline \multirow{2}{*}{$\begin{array}{c}\text { Animal and TBI } \\
\text { Model }\end{array}$} & \multirow{2}{*}{$\begin{array}{c}\text { Age } \\
\text { (Aged) }\end{array}$} & \multirow{2}{*}{$\begin{array}{l}\text { Compa-rison } \\
\text { Age } \\
\text { (YA) }\end{array}$} & \multicolumn{3}{|c|}{ Main Highlights } & \multirow[b]{2}{*}{ Reference } \\
\hline & & & Microglia & Astrocytes & $\begin{array}{c}\text { Cytokines and Other Immune } \\
\text { Cells }\end{array}$ & \\
\hline $\begin{array}{l}\text { Mice } \\
\text { LFP, open skull, } \\
\text { unilateral }\end{array}$ & M12 & M1.5/3 & $\begin{array}{l}\text { - activation aged }>>\text { YA at } 7 \text { and } \\
28 \mathrm{~d}\end{array}$ & $\begin{array}{l}\text { - activation aged }>>Y A \text { at } 7 \text { and } 28 \\
\text { d }\end{array}$ & & [199] \\
\hline $\begin{array}{l}\text { Mice } \\
\text { CCI, open skull, } \\
\text { unilateral }\end{array}$ & M18 & M3 & $\begin{array}{l}\text { - number aged }<\text { YA at baseline } \\
\text { and } 3 \mathrm{~d} \\
-\uparrow \text { aged }>\text { YA at } 3 \mathrm{~d} \\
-\downarrow \text { phagocytic capacities in aged at } \\
3 \mathrm{~d}\end{array}$ & & $\begin{array}{l}\text { - TNF } \alpha \text {, and IL- } 1 \beta \text { expression aged } \\
>\mathrm{YA} \text { at } 3 \mathrm{~d} \\
\text { - } \uparrow \text { immune cells infiltration at } 3 \mathrm{~d}\end{array}$ & [200] \\
\hline $\begin{array}{l}\text { Mice } \\
\text { CCI, open skull, } \\
\text { unilateral }\end{array}$ & M18 & M4 & & $\begin{array}{l}\text { - activation in aged from } 1 \text { to } 7 \mathrm{~d} \\
\text { (hippocampus and cortex) } \\
\text { - Activation in YA from } 1 \text { to } 3 \mathrm{~d} \\
\text { - Gene expression of reactive } \\
\text { astrocytes, inflammatory response, } \\
\text { complement pathway, and synaptic } \\
\text { support are modified in aged } \\
\text { - Loss of astrocytes function and } \\
\text { astrogliopathy in aged } \\
\text { - No clear dichotomy A1/A2 in aged }\end{array}$ & & [201] \\
\hline $\begin{array}{l}\text { Mice } \\
\text { CCI, open skull, } \\
\text { unilateral }\end{array}$ & M19 & NC & $\begin{array}{l}-\uparrow \text { at } 7 \text { and } 30 \mathrm{~d} \text { (hippocampus) } \\
-\uparrow \text { at } 10 \text { and } 30 \mathrm{~d} \text { (total brain) } \\
-\uparrow \text { phagocytic activity at } 30 \text { but } \\
\text { not } 10 \mathrm{~d}\end{array}$ & & & [202] \\
\hline $\begin{array}{l}\text { Mice } \\
\text { CCI, open skull, } \\
\text { unilateral }\end{array}$ & M20/25 & $\mathrm{M} 3 / 6$ & & & $\begin{array}{l}-\uparrow \text { pro-inflammatory markers } \\
\text { (IL-1 } \beta, T N F \alpha \text {, and iNOS) in aged at } \\
7 \mathrm{~d} \\
-\downarrow \text { anti-inflammatory markers (Ym1, } \\
\mathrm{CD} 206, \mathrm{TGF} \beta \text {, and IL-4Ra) in aged } \\
\text { at } 7 \mathrm{~d} \\
\text { - chemotactic ligands expression } \\
\text { aged > YA at } 4 \text { and } 7 \mathrm{~d} \\
\text { - monocyte infiltration aged > YA at } \\
4 \text { and } 7 \mathrm{~d}\end{array}$ & [203] \\
\hline
\end{tabular}


Table 4. Cont.

\begin{tabular}{|c|c|c|c|c|c|c|}
\hline \multirow{2}{*}{$\begin{array}{l}\text { Animal and TBI } \\
\text { Model }\end{array}$} & \multirow{2}{*}{$\begin{array}{c}\text { Age } \\
\text { (Aged) }\end{array}$} & \multirow{2}{*}{$\begin{array}{l}\text { Compa-rison } \\
\text { Age } \\
\text { (YA) }\end{array}$} & \multicolumn{3}{|c|}{ Main Highlights } & \multirow[b]{2}{*}{ Reference } \\
\hline & & & Microglia & Astrocytes & $\begin{array}{l}\text { Cytokines and Other Immune } \\
\text { Cells }\end{array}$ & \\
\hline $\begin{array}{l}\text { Mice } \\
\text { CCI, open skull, } \\
\text { unilateral }\end{array}$ & M21 & M2 & & & $\begin{array}{l}\text { - IL- } 1 \beta, \text { TNF } \alpha \text { and IL- } 6 \text { expression } \\
\text { aged > YA at baseline } \\
\text { - IL-1 } \beta \text { expression in aged > YA at } 3 \\
\text { d }\end{array}$ & [204] \\
\hline $\begin{array}{l}\text { Mice } \\
\text { CCI, open skull, } \\
\text { unilateral }\end{array}$ & M21 & M2 & $\begin{array}{l}\text { - M2a phenotype aged }>\text { YA at } 1 \mathrm{~d} \\
\text { - M2a phenotype aged < YA at } 5 \mathrm{~d}\end{array}$ & & $\begin{array}{l}\text { - inflammatory markers expression } \\
\text { aged } \neq \mathrm{YA} \text { at } 1 \text { and } 5 \mathrm{~d}\end{array}$ & [205] \\
\hline $\begin{array}{l}\text { Mice } \\
\text { CCI, open skull, } \\
\text { unilateral }\end{array}$ & M21/24 & $\mathrm{M} 5 / 6$ & $\begin{array}{l}\text { - number aged > YA at baseline } \\
\text { and from } 1 \text { to } 28 \mathrm{~d} \text { (hippocampus) }\end{array}$ & $\begin{array}{l}\text { - number aged > YA at baseline and } \\
\text { from } 1 \text { to } 28 \mathrm{~d} \text { (hippocampus) }\end{array}$ & & [206] \\
\hline $\begin{array}{l}\text { Mice } \\
\text { CCI, open skull, } \\
\text { unilateral }\end{array}$ & M21/24 & $\mathrm{NC}$ & $-\uparrow$ at 30 and $60 \mathrm{~d}$ (thalamus) & & & [207] \\
\hline $\begin{array}{l}\text { Mice } \\
\text { LFP, open skull, } \\
\text { unilateral }\end{array}$ & M22/25 & $\mathrm{M} 5 / 6$ & & & $\begin{array}{l}\text { - cytokine expression profile aged } \neq \\
\text { YA }\end{array}$ & [208] \\
\hline $\begin{array}{l}\text { Mice } \\
\text { CCI, open skull, } \\
\text { unilateral }\end{array}$ & M24 & M3 & $\begin{array}{l}\text { - activation aged }>\text { YA at } 7 \mathrm{~d} \\
\text { (cortex and hippocampus) } \\
\text { - M1 phenotype genes expression } \\
\text { levels aged }>\text { YA at } 1 \mathrm{~d} \text { (cortex) } \\
\text { - variation in M2a phenotype } \\
\text { genes expression at } 1 \mathrm{~d} \text { (cortex) } \\
\text { - M2c phenotype genes expression } \\
\text { aged }<\text { YA at } 1 \mathrm{~d} \text { (cortex) }\end{array}$ & & & [210] \\
\hline
\end{tabular}


Table 4. Cont.

\begin{tabular}{|c|c|c|c|c|c|c|}
\hline \multirow{2}{*}{$\begin{array}{c}\text { Animal and TBI } \\
\text { Model }\end{array}$} & \multirow{2}{*}{$\begin{array}{c}\text { Age } \\
\text { (Aged) }\end{array}$} & \multirow{2}{*}{$\begin{array}{l}\text { Compa-rison } \\
\text { Age } \\
\text { (YA) }\end{array}$} & \multicolumn{3}{|c|}{ Main Highlights } & \multirow[b]{2}{*}{ Reference } \\
\hline & & & Microglia & Astrocytes & $\begin{array}{l}\text { Cytokines and Other Immune } \\
\text { Cells }\end{array}$ & \\
\hline $\begin{array}{l}\text { Rats } \\
\text { LFP, open skull, } \\
\text { unilateral }\end{array}$ & M12 & W10 & & & $\begin{array}{l}\text { - number of leukocytes, myeloid } \\
\text { cells and microglia aged < YA } \\
\text { (ipsilateral hemisphere) }\end{array}$ & [211] \\
\hline $\begin{array}{l}\text { Rats } \\
\text { Penetrating TBI, } \\
\text { open skull, } \\
\text { unilateral }\end{array}$ & M20/22 & M5/12 & - number aged $<\mathrm{YA}$ at $2 \mathrm{~d}$ & - number aged $>$ YA at $2 \mathrm{~d}$ & & [212] \\
\hline
\end{tabular}




\subsubsection{Post-Traumatic Inflammatory Consequences}

Published data on post-traumatic inflammatory consequences on aged animals are summarized in Table 4.

Microglia

Microglial activation induced by TBI in aged rodents occurs from 1 to $60 \mathrm{dpi}$ and follow the same time/activation pattern than in young adults, but is exacerbated in older animals $[199,200,202,206,207,209,210]$. This could be explained by an alteration of microglia in aged brains, both quantitatively and qualitatively. Indeed, studies reported either a decrease [200] or an increase [206] in the absolute basal number of microglia in aged brains. Age also increases the expression of senescence markers in resident microglia, increasing their sensitivity to TBI and altering their proliferation potentials, phagocytic behavior and cytokinic profiles [200]. Moreover, microglial and infiltrating monocyte phagocytic capacities are impaired in aged brains compared with those of young adults, suggesting impairments regarding debris clearance mechanisms and the phagocytic removal of damaged cells in immune cells from aged rodents [200].

The different microglial phenotypes have not been deeply studied, but at $1 \mathrm{dpi}$, the M1 phenotype and most of the M2a phenotype genes are highly upregulated compared with young adults, in contrast with the M2c phenotype genes, which are downregulated [210]. Another study reported the reduced expression of M2a genes in aged TBI at $1 \mathrm{dpi}$ compared with young adults, but this ratio was reversed at 5 dpi [205].

In the absence of any longitudinal study of phenotype-gene expression, it is difficult to establish a precise profile of microglial activation, but all these data highlight a different microglial activation profile in aged brains compared with young adults.

\section{Astrocytes}

As concerns microglia, astrocyte activation following TBI differs in aged compared with young adult populations. Astrocyte activation peaks and decreases earlier in young adult brains $[201,206]$. In aged brains, astrocyte activation is higher and persists longer, up to $60 \mathrm{~d}[199,206,207]$. Moreover, a study reported the presence of degenerative astrocytes and the decrease of endfoot integrity following TBI in aged mice, but not in young adults [201]. Also, gene expression profile and astrocyte activation phenotype are different in aged TBI [201]. This implies that the astrocytic response after injury is altered both quantitatively and qualitatively in aged brains as compared with young brains.

Other immune cells' and cytokines' expression

The leukocyte infiltration process is also altered qualitatively and quantitatively. Qualitatively, more infiltration by neutrophils and fewer by monocytes was observed [200]. Quantitatively, the recruitment process in aged mice is emphasized and subchronically exacerbated as more newly recruited leukocytes are present in their brains than in those of young adults from 1 to 7 dpi $[200,203,205,209]$. However, a study reported altered neuroimmune response with fewer leukocytes infiltrating myeloid cells and microglia at 1 and $7 \mathrm{dpi}$ in aged TBI rats, compared with young adults [211]. One explanation could stand on the dysregulation of chemokines' expression, observed from $1 \mathrm{dpi}$ in aged mice, with a decrease of anti-inflammatory chemokine CRX3CL1 and an upregulation of other chemokines' expression between 4 and $7 \mathrm{dpi}$ [209]. Moreover, after $7 \mathrm{dpi}$, the expression of most chemokines was unchanged, in contrast with young adults, whose expression of the same decreased [203].

Cytokine production is also different in aged mice. The baseline expression of some pro-inflammatory cytokines, such as IL- $1 \beta$, TNF $\alpha$, iNOS and IL-6, and chemokines, like MCP-1, are already higher in aged animals compared with young adults [205], indicating a subclinical chronic inflammatory process in the elderly, referred to as "inflamm-aging" [204]. The overall pattern of inflammatory protein expression differs between aged and young adults. Specifically, IL-1 $\beta$ and TNF $\alpha$ expressions peak earlier [204] and IL-6 expression decreases earlier [203] in aged animals. At $7 \mathrm{dpi}$, the expression of pro-inflammatory markers is similar between young adult and aged animals, but anti-inflammatory markers appear reduced in aged animals [203]. 
Interestingly, although overall cytokine expression is increased in aged animals, the production thereof seemed to be decreased in infiltrated leukocytes [200].

\subsubsection{Post-Traumatic Neuronal, Tissue and Functional Consequences}

Published data on post-traumatic neuronal, tissue and functional consequences on aged animals are summarized in Table 5. 


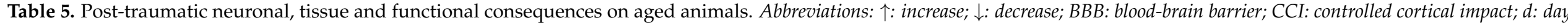
post-injury; FP: fluid percussion; h: hour post-injury; LFP: lateral fluid percussion; M: post-natal month; NC: not compared; TBI: traumatic brain injury; W: post-natal week; YA: young adult.

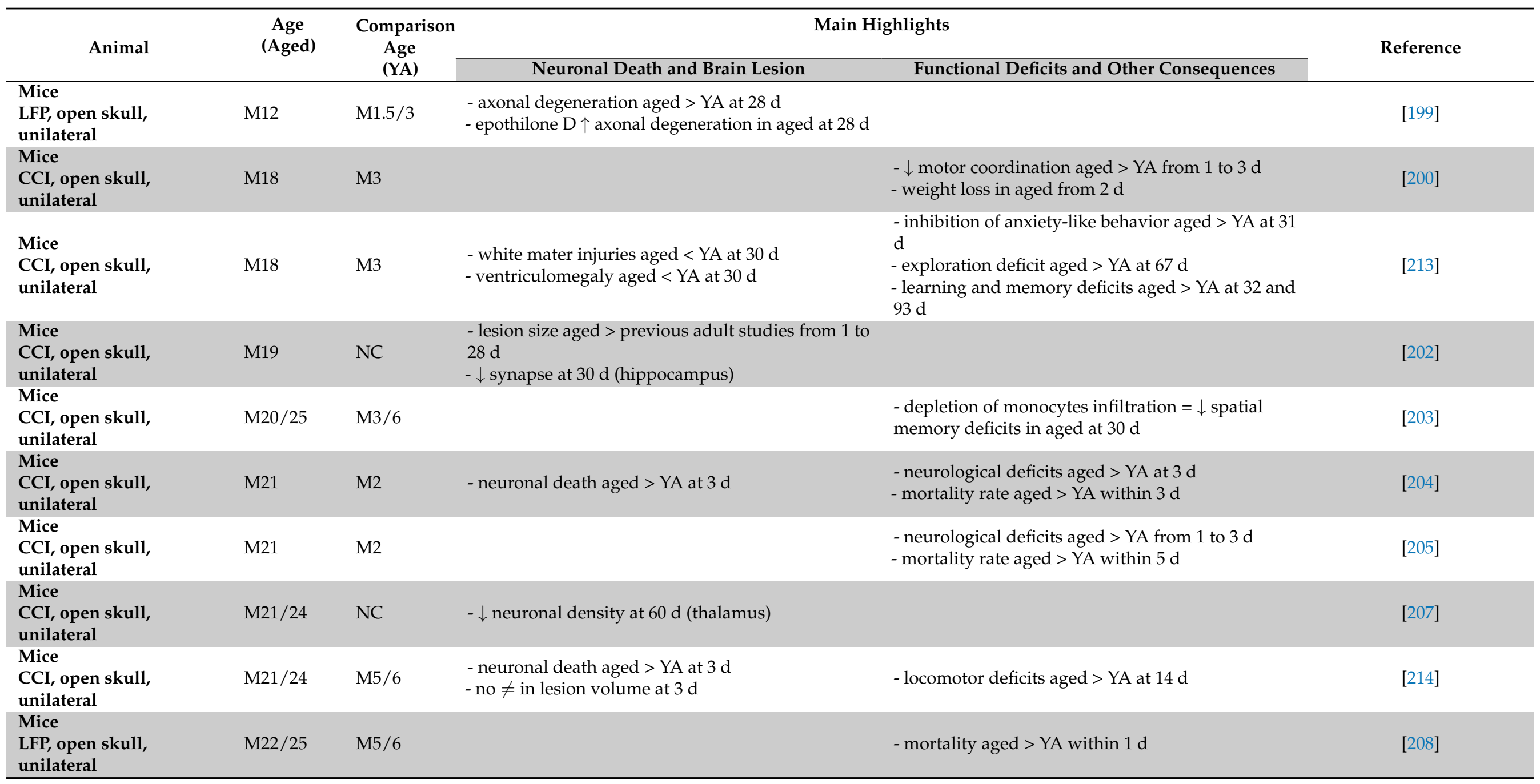


Table 5. Cont.

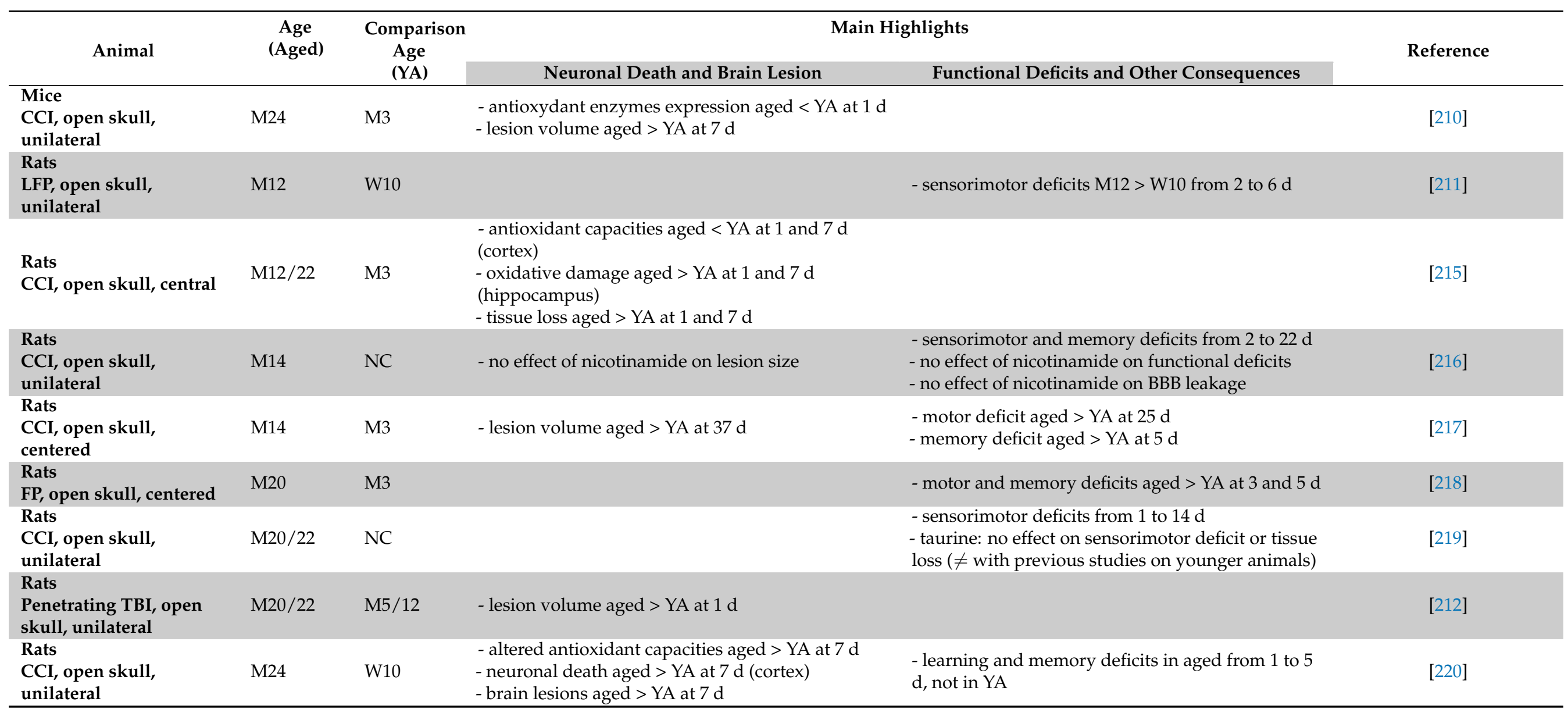




\section{Antioxidant response}

In humans, brains' antioxidant capacity decreases with age. Thus, some studies have shown interest in the antioxidant response in aged rodents. Following TBI, these animals show increased free radical production and lipid peroxidation $[129,215,220]$. Their overall antioxidant enzyme capacities are reduced at 1 and 7 dpi $[129,210,215]$ and thus overwhelmed, resulting in a stronger oxidative stress response [220]. This stronger oxidative stress response might be one of the explanations for the exacerbated alteration of microglial activation and neuronal death seen at this age.

Neuronal death

Neurodegeneration and neuronal death are exacerbated at 3 and $7 \mathrm{dpi}$ in the damaged area and hippocampus of aged mice, as compared with young adults [204,210,214,220]. Aged mice also showed more important WMI than young adults [213]. The evolution of axonal injuries differs by age, with early injury at $7 \mathrm{dpi}$ in younger animals resolved by $28 \mathrm{dpi}$, whereas, in older animals, axonal injuries are less severe at $7 \mathrm{dpi}$ but worsen by 28 dpi [199]. TBI also induces a decrease of synapse number in aged mice [203].

Lesion size

From 1 to $28 \mathrm{dpi}$, lesion volume is higher in aged mice than in young adults [203,210,212,220]. However, these results are inconsistent, especially at 3 dpi $[204,205,214]$, as the cortical thickness and axonal degeneration are not systematically altered in aged mice [199].

\section{Functional deficits}

Age-related deficits in neurobehavioral functions consecutive to TBI are associated with weight loss and cognitive and behavioral deficits [200]. Indeed, TBI induces deficits in learning and memory, locomotor and motor coordination and anxiety-like behaviors [200,202,214,217,220]. Compared with young adults, aged mice show more important sensori- and locomotor [200,211,214,217,218], anxiety-like, exploratory behavior [213] and learning and memory deficits $[213,217,218,220]$. These neurobehavioral deficits persist up to 3 mpi [213].

Mortality rate

Globally, mortality is exacerbated in aged mice compared with young adults, as there is a higher death rate after $\mathrm{TBI}$, from $+18 \%$ at $1 \mathrm{dpi}$ to $+22 \%$ at $3 \mathrm{dpi}$ for aged rodent compared with young adults [204,205,208].

\subsubsection{Anti-Inflammatory and Neuroprotective Therapeutic Strategies}

The response to therapeutic strategies following TBI is not the same in aged TBI models compared with young adults.

Following TBI, inhibition of monocyte/macrophage infiltration in aged mice prevents spatial memory deficits [203] to a greater extent than in young adult mice [104].

Conversely, some neuroprotective strategies, such as the administration of taurine, an endogenous amino acid with antioxidant, anti-inflammatory and anti-apoptotic effects, and which is neuroprotective in adult TBI [221], is not effective following TBI in aged animals [219]. Moreover, nicotinamide, which improves functional outcome following young adult TBI [196], does not enhance functional recovery at low doses and even worsens functional deficit with higher doses [216]. The same phenomenon is observed with epothilone $\mathrm{D}$, a cytoskeletal stabilizing agent used as an axonal protection therapy following TBI in young adult [222], which is actually detrimental to axonal integrity following TBI in aged animals [199].

These studies confirm that the response to different neuroprotective strategies varies with age. Thus, in addition to studying variation in consequences in terms of neuroinflammation, neuronal loss and functional deficits, the response to novel therapies must be studied in each age category.

\subsubsection{Conclusions}

The investigation of the posttraumatic neuroinflammation pathway and its consequences in aged animals has just begun. Aged mice show altered basal inflammatory status, 
with higher levels of pro-inflammatory cytokines, senescence markers in their resident microglia and impairment of immune cells' phagocytic capacities, compared with young adults [200]. This could explain the different inflammatory process in aged mice, especially their cytokine expression and glial activation $[199,200,202,206,207,209,210]$. This higher microglial activation may induce a vulnerability to secondary insults and promote psychological stress, and may, itself, exacerbate microglial activation [223]. Also, aged animals show poorer antioxidant capacities [129,210,215], poorer functional reserves and a decrease in neuronal plasticity [204]. This results in greater predisposition to neuronal loss and, thus, to loss of function, dementia-like symptoms and neurodegenerative pathologies [129]. It suggests that, following TBI, the aged brain is more reactive to neuroinflammation than the adult brain, and more vulnerable to neurodegeneration. This could explain the greater functional deficits and higher mortality rate, following TBI, in aged rodents, as compared with adults [200,202,204,205,208,211,213,214,217,218]

Administration of anti-inflammatory or neuroprotective components, like nicotinamide, taurine or epothilone, revealed no effect or even worsened tissue loss and functional deficit in aged TBI mice $[199,216,219]$. Altogether, these studies illustrate the complexity of age-dependent mechanism of the consequences of TBI and the necessity to consider its singularity in treatments of aged populations.

Finally, all these studies assessed the consequences of TBI on "healthy" aged animals, which does not reflect the clinical reality, where elderly populations often suffer from other diseases like hypertension, kidney failure or neurodegenerative disease, that could alter neuroinflammation response even more [224-226]. Notably, a repetitive TBI model induced worse neurobehavioral impairments in an Alzheimer's disease mice model than in a "healthy"-aged models [227].

\section{Conclusions}

TBI is most prevalent disease worldwide and can have the most devastating consequences in newborns, juvenile/adolescent and aged animals, due to the characteristics of developing or senescent brains. Yet, today, few preclinical studies have focused on post-traumatic neuroinflammation and its consequences at these ages. In this review, we have shown that the inflammatory brain response to and the neurological consequences of TBI vary with age. Indeed, immature or senescent brains do not show the same immune cell reactivity, antioxidant capacities or neuronal plasticity. For example, antioxidant enzyme capacities are diminished in aged rodents and the effect of stimulating GABA receptors is reversed in neonate rodents. These factors could help to explain the difference in the effects of strategies that are usually neuroprotective in young adults following TBI, but which are ineffective or even deleterious in neonates, juvenile, adolescent or aged animals (Table 6). Indeed, this review shows that, in neonates, strategies that are usually neuroprotective in young adults (administration of minocycline, cromoglycate), have been shown to be not or only transiently effective. The same phenomenon is observed in aged animals, with molecules that have demonstrated neuroprotective properties in young adults (taurine, nicotinamide, epothilone D) having no effect or even worsening neuronal loss. Interestingly, despite inconsistent results, the therapeutic strategies that are effective in adults seem to be equally effective in adolescents/juveniles. These studies confirm the need for an age-specific approach to developing neuroprotective strategies for the prevention and treatment of the consequences of TBI. Thus, the most effective research strategy might be to identify lesion mechanisms by age in order to develop therapeutic strategies adapted to each age, rather than extrapolating the results obtained in adults to other ages.

Additionally, we currently lack direct comparative studies between ages. This is due to the difficulty in comparing the consequences of TBI between any given two ages using the same impact parameters. Brain size and plasticity vary depending on age, so the same impact parameters may correspond to different TBI severity, depending on age. It might be necessary to adapt impact parameters according to age, but this is necessarily done approximatively and empirically. Moreover, it is tricky to transpose these results to 
humans, due to the differences between rodent and human brains. Firstly, most preclinical studies are conducted on rodents whose brains are divided into two hemispheres, unlike humans. Most of the time, TBI is performed on a single hemisphere, which cannot be the case in humans. This can induce a variation in the induced cellular and molecular responses to TBI. Secondly, the classification of rodents according to their age is based on the chronology of brain development. This evolution may follow a different temporality if it is based on different criteria, such as metabolism or immunity.

Finally, almost all the studies conducted at ages other than adult have been conducted in male animals. It is known that the consequences, in term of neuroinflammation, neuronal death and functional deficits, vary by sex $[228,229]$. For example, following TBI in adolescence, sex-dependent alterations in executive function are seen in early adulthood [228]. Thus, studies of the consequences of TBI on females of extreme age are also needed to complete our knowledge of TBI. 


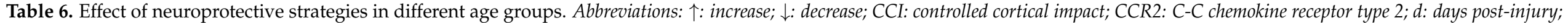

LFP: lateral fluid percussion; M: post-natal months; P: post-natal days; TBI: traumatic brain injury; WD: weight drop.

\begin{tabular}{|c|c|c|c|c|c|}
\hline Animal and TBI Model & Age & $\begin{array}{l}\text { Molecule or } \\
\text { Strategy }\end{array}$ & $\begin{array}{c}\text { Effect on Post-Traumatic Inflammatory, Neuronal and } \\
\text { Functional Consequences }\end{array}$ & Reference & Effects Observed in Adult TBI \\
\hline \multicolumn{6}{|c|}{ Neonates } \\
\hline $\begin{array}{l}\text { Mice } \\
\text { WD, closed head, unilateral }\end{array}$ & P7 & minocycline & $\begin{array}{l}-\downarrow \text { microglia number at } 1 \mathrm{~d} \\
-\downarrow \text { ventricular dilatation and neuronal loss at } 1 \mathrm{~d} \\
\text { - no effect at } 5 \mathrm{~d}\end{array}$ & [144] & $\begin{array}{l}-\downarrow \text { microglial activation [194] } \\
-\downarrow \text { lesion size [194] } \\
-\downarrow \text { functional deficits [194] }\end{array}$ \\
\hline $\begin{array}{l}\text { Mice } \\
\text { WD, closed head, unilateral }\end{array}$ & P7 & cromoglycate & $\begin{array}{l}-\downarrow \text { microglial activation markers at } 1 \text { and } 5 \mathrm{~d} \\
\text { - no effect on microglial number at } 1 \text { and } 5 \mathrm{~d} \\
\text { - no effect on neuronal and tissue loss at } 1 \text { and } 5 \mathrm{~d}\end{array}$ & [143] & $\begin{array}{l}-\downarrow \text { infiltrating mast cells } \\
\text { degranulation [155] } \\
-\downarrow \text { microglial activation }[230]\end{array}$ \\
\hline $\begin{array}{l}\text { Rats } \\
\text { CCI, open skull, unilateral }\end{array}$ & P17 & \multirow[b]{2}{*}{$\begin{array}{l}\text { docosahexaenoic } \\
\text { acid }\end{array}$} & $\begin{array}{l}-\downarrow \text { brain atrophy and white matter injury at } 3 \text { and } 12 \mathrm{~d} \\
-\downarrow \text { acquisition deficits at } 40 \mathrm{~d}\end{array}$ & [173] & \multirow{2}{*}{$\begin{array}{l}-\downarrow \text { microglial and astrocytic } \\
\text { activation [231] } \\
-\downarrow \text { neuronal loss [193] } \\
-\downarrow \text { lesion size [231] } \\
-\downarrow \text { functional deficits [231] }\end{array}$} \\
\hline $\begin{array}{l}\text { Rats } \\
\text { CCI, open skull, unilateral }\end{array}$ & P17 & & $\begin{array}{l}-\downarrow \text { microglial and astrocytic activation at } 3 \text { and } 7 \mathrm{~d} \\
-\downarrow \text { memory deficits at } 14 \mathrm{~d}\end{array}$ & [175] & \\
\hline $\begin{array}{l}\text { Rats } \\
\text { CCI, open skull, unilateral }\end{array}$ & P17 & minocycline & $\begin{array}{l}-\downarrow \text { microglial activation at } 7 \mathrm{~d} \\
-\downarrow \text { neuronal loss at } 7 \text { and } 14 \mathrm{~d} \\
- \text { delays motor recovery at } 5 \mathrm{~d} \\
-\downarrow \text { memory deficits at } 14 \mathrm{~d}\end{array}$ & [174] & $\begin{array}{l}-\downarrow \text { microglial activation [194] } \\
-\downarrow \text { lesion size [194] } \\
-\downarrow \text { functional deficits [194] }\end{array}$ \\
\hline $\begin{array}{l}\text { Mice } \\
\text { CCI, open skull, unilateral }\end{array}$ & $\mathrm{P} 42$ & dexamethasone & $\begin{array}{l}-\downarrow \text { microglial and astrocytic activation from } 1 \text { to } 14 \mathrm{~d} \\
-\downarrow \text { peripheral immune cell recruitment } \\
-\downarrow \text { cognitive and behavioral deficits }\end{array}$ & [165] & $\begin{array}{l}-\downarrow \text { microglial activation [232] } \\
-\downarrow \text { apoptosis [233] } \\
-\downarrow \text { lesion size [233] }\end{array}$ \\
\hline $\begin{array}{l}\text { Mice } \\
\text { CCI, closed head, unilateral }\end{array}$ & P35 & isoflurane & $\begin{array}{l}-\downarrow \text { microglial activation at } 1 \mathrm{~d} \\
-\downarrow \text { axonal injury at } 1 \mathrm{~d}\end{array}$ & [164] & $\begin{array}{l}-\downarrow \text { neuronal loss [195] } \\
-\downarrow \text { cognitive deficits [195] }\end{array}$ \\
\hline $\begin{array}{l}\text { Rats } \\
\text { CCI, open skull, unilateral }\end{array}$ & $\mathrm{P} 28$ & nicotinamide & $\begin{array}{l}-\downarrow \text { microglial activation at } 3 \text { and } 7 \mathrm{~d} \\
-\downarrow \text { cortical tissue loss only at } 3 \mathrm{~d} \text {, not at } 7 \text { and } 30 \mathrm{~d} \\
\text { - no effect on acquisition, locomotor and sensorimotor deficits } \\
\text { at } 30 \mathrm{~d}\end{array}$ & [179] & $\begin{array}{l}-\downarrow \text { microglial activation }[234] \\
-\downarrow \text { lesion size [196] } \\
-\downarrow \text { behavioral deficits }[234]\end{array}$ \\
\hline \multicolumn{6}{|c|}{ Aged } \\
\hline $\begin{array}{l}\text { Mice } \\
\text { CCI, open skull, unilateral }\end{array}$ & M20/25 & $\begin{array}{l}\text { CCR2 knockout } \\
\text { mice } \\
\text { (macrophage } \\
\text { infiltration } \\
\text { inhibition) }\end{array}$ & $-\downarrow$ spatial memory deficits aged $>$ young adult at $30 \mathrm{~d}$ & [203] & $\begin{array}{l}-\downarrow \text { cytokines expression }[235] \\
-\downarrow \text { neuronal loss [235] } \\
-\downarrow \text { locomotor and learning } \\
\text { deficits }[235]\end{array}$ \\
\hline
\end{tabular}


Table 6. Cont

\begin{tabular}{|c|c|c|c|c|c|}
\hline Animal and TBI Model & Age & $\begin{array}{l}\text { Molecule or } \\
\text { Strategy }\end{array}$ & $\begin{array}{c}\text { Effect on Post-Traumatic Inflammatory, Neuronal and } \\
\text { Functional Consequences }\end{array}$ & Reference & Effects Observed in Adult TBI \\
\hline $\begin{array}{l}\text { Rats } \\
\text { CCI, open skull, unilateral }\end{array}$ & M20/22 & taurine & $\begin{array}{l}\text { - No effect on tissue loss } \\
\text { - No effect on sensorimotor deficits }\end{array}$ & [219] & $\begin{array}{l}-\downarrow \text { astrocytic activation [221] } \\
-\downarrow \text { pro-inflammatory cytokines } \\
\text { [221] } \\
-\downarrow \text { neuronal loss [236] } \\
-\downarrow \text { functional deficits [221] }\end{array}$ \\
\hline $\begin{array}{l}\text { Rats } \\
\text { CCI, open skull, unilateral }\end{array}$ & M14 & nicotinamide & & [216] & $\begin{array}{l}\downarrow \downarrow \text { microglial activation [234] } \\
-\downarrow \text { lesion size [196] } \\
-\downarrow \text { behavioural deficits [234] }\end{array}$ \\
\hline $\begin{array}{l}\text { Mice } \\
\text { LFP, open skull, unilateral }\end{array}$ & M12 & epothilone D & & [199] & $\begin{array}{l}-\downarrow \text { axonal injury [222] } \\
-\downarrow \text { functional deficits [237] }\end{array}$ \\
\hline
\end{tabular}


In conclusion, most of the preclinical studies evaluating the consequences of TBI are conducted on young male adults. This does not reflect the clinical reality, and we question it, since our review highlights the variability of response by age. The complexity of performing TBI research on extreme ages and in comparing between different models leaves the consequences of TBI difficult to study. However, researchers should not give up, as it is crucial to know, precisely, all the mechanisms underlying the consequences of TBI in order to develop effective neuroprotective strategies.

Author Contributions: Conceptualization, C.D. and V.C.B.; literature review, C.D., T.T., C.M., D.L.; writing-original draft preparation, C.D.; writing-review and editing, C.D., V.C.B. All authors have read and agreed to the published version of the manuscript.

Funding: This work was supported by a grant from the "Fondation des Gueules Cassées" (n 10-2020 to VCB).

Conflicts of Interest: The authors declare no conflict of interest.

$\begin{array}{ll}\text { Abbreviations } \\ \text { BBB } & \text { blood-brain barrier } \\ \text { CNS } & \text { central nervous system } \\ \text { dpi } & \text { days post-injury } \\ \text { hpi } & \text { hours post-injury } \\ \text { M } & \text { post-natal months } \\ \text { MBP } & \text { myelin basic protein } \\ \text { mpi } & \text { month post-injury } \\ \text { P } & \text { post-natal days } \\ \text { TBI } & \text { traumatic brain injury } \\ \text { W } & \text { post-natal weeks } \\ \text { WMI } & \text { white matter injury }\end{array}$

\section{References}

1. Menon, D.K.; Schwab, K.; Wright, D.W.; Maas, A.I. Position Statement: Definition of Traumatic Brain Injury. Arch. Phys. Med. Rehabil. 2010, 91, 1637-1640. [CrossRef]

2. Maas, A.I.R.; Menon, D.K.; Steyerberg, E.W.; Citerio, G.; Lecky, F.; Manley, G.T.; Hill, S.; Legrand, V.; Sorgner, A. CENTERTBI Participants and Investigators Collaborative European NeuroTrauma Effectiveness Research in Traumatic Brain Injury (CENTER-TBI). Neurosurgery 2015, 76, 67-80. [CrossRef]

3. Blennow, K.; Brody, D.L.; Kochanek, P.M.; Levin, H.; McKee, A.; Ribbers, G.M.; Yaffe, K.; Zetterberg, H. Traumatic brain injuries. Nat. Rev. Dis. Prim. 2016, 2, 16084. [CrossRef] [PubMed]

4. Maas, A.I.R.; Menon, D.K.; Adelson, P.D.; Andelic, N.; Bell, M.J.; Belli, A.; Bragge, P.; Brazinova, A.; Büki, A.; Chesnut, R.M.; et al. Traumatic brain injury: Integrated approaches to improve prevention, clinical care, and research. Lancet Neurol. 2017, 16, 987-1048. [CrossRef]

5. Peeters, W.; van den Brande, R.; Polinder, S.; Brazinova, A.; Steyerberg, E.W.; Lingsma, H.F.; Maas, A.I.R. Epidemiology of traumatic brain injury in Europe. Acta Neurochir. 2015, 157, 1683-1696. [CrossRef] [PubMed]

6. Faul, M.; Coronado, V. Epidemiology of traumatic brain injury. In Handbook of Clinical Neurology; Elsevier B.V.: Amsterdam, The Netherlands, 2015; Volume 127, pp. 3-13.

7. McGinn, M.J.; Povlishock, J.T. Pathophysiology of Traumatic Brain Injury. Neurosurg. Clin. N. Am. 2016, 27, 397-407. [CrossRef] [PubMed]

8. Finnie, J.W. Neuroinflammation: Beneficial and detrimental effects after traumatic brain injury. Inflammopharmacology 2013, 21, 309-320. [CrossRef]

9. Nizamutdinov, D.; Shapiro, L.A. Overview of Traumatic Brain Injury: An Immunological Context. Brain Sci. 2017, 7, 11. [CrossRef]

10. Cherry, J.D.; Olschowka, J.A.; O'Banion, M.K. Neuroinflammation and M2 microglia: The good, the bad, and the inflamed. J. Neuroinflammation 2014, 11,98. [CrossRef]

11. Karve, I.P.; Taylor, J.M.; Crack, P.J. The contribution of astrocytes and microglia to traumatic brain injury. Br. J. Pharmacol. 2016, 173, 692-702. [CrossRef]

12. Colonna, M.; Butovsky, O. Microglia Function in the Central Nervous System During Health and Neurodegeneration. Annu. Rev. Immunol. 2017, 35, 441-468. [CrossRef]

13. Loane, D.J.; Kumar, A. Microglia in the TBI brain: The good, the bad, and the dysregulated. Exp. Neurol. 2016, 275 Pt 3, $316-327$. [CrossRef] 
14. Donat, C.K.; Scott, G.; Gentleman, S.M.; Sastre, M. Microglial Activation in Traumatic Brain Injury. Front. Aging Neurosci. 2017, 9, 208. [CrossRef]

15. Ransohoff, R.M. A polarizing question: Do M1 and M2 microglia exist? Nat. Neurosci. 2016, 19, 987-991. [CrossRef]

16. Kumar, A.; Alvarez-Croda, D.-M.; Stoica, B.A.; Faden, A.I.; Loane, D.J. Microglial/Macrophage Polarization Dynamics following Traumatic Brain Injury. J. Neurotrauma 2016, 33, 1732-1750. [CrossRef] [PubMed]

17. Butovsky, O.; Ziv, Y.; Schwartz, A.; Landa, G.; Talpalar, A.E.; Pluchino, S.; Martino, G.; Schwartz, M. Microglia activated by IL-4 or IFN- $\gamma$ differentially induce neurogenesis and oligodendrogenesis from adult stem/progenitor cells. Mol. Cell. Neurosci. 2006, 31, 149-160. [CrossRef] [PubMed]

18. Hu, X.; Li, P.; Guo, Y.; Wang, H.; Leak, R.K.; Chen, S.; Gao, Y.; Chen, J. Microglia/macrophage polarization dynamics reveal novel mechanism of injury expansion after focal cerebral ischemia. Stroke 2012, 43, 3063-3070. [CrossRef] [PubMed]

19. Wang, G.; Zhang, J.; Hu, X.; Zhang, L.; Mao, L.; Jiang, X.; Liou, A.K.-F.; Leak, R.K.; Gao, Y.; Chen, J. Microglia/macrophage polarization dynamics in white matter after traumatic brain injury. J. Cereb. Blood Flow Metab. 2013, 33, 1864-1874. [CrossRef]

20. Girard, S.; Brough, D.; Lopez-Castejon, G.; Giles, J.; Rothwell, N.J.; Allan, S.M. Microglia and macrophages differentially modulate cell death after brain injury caused by oxygen-glucose deprivation in organotypic brain slices. Glia 2013, 61, 813-824. [CrossRef] [PubMed]

21. Wang, G.; Shi, Y.; Jiang, X.; Leak, R.K.; Hu, X.; Wu, Y.; Pu, H.; Li, W.-W.; Tang, B.; Wang, Y.; et al. HDAC inhibition prevents white matter injury by modulating microglia/macrophage polarization through the GSK3 $\beta /$ PTEN/Akt axis. Proc. Natl. Acad. Sci. USA 2015, 112, 2853-2858. [CrossRef]

22. Dent, K.A.; Christie, K.J.; Bye, N.; Basrai, H.S.; Turbic, A.; Habgood, M.; Cate, H.S.; Turnley, A.M. Oligodendrocyte birth and death following traumatic brain injury in adult mice. PLoS ONE 2015, 10, e0121541. [CrossRef]

23. Robinson, S.; Miller, R.H. Contact with central nervous system myelin inhibits oligodendrocyte progenitor maturation. Dev. Biol. 1999, 216, 359-368. [CrossRef]

24. Baer, A.S.; Syed, Y.A.; Kang, S.U.; Mitteregger, D.; Vig, R.; ffrench-Constant, C.; Franklin, R.J.M.; Altmann, F.; Lubec, G.; Kotter, M.R. Myelin-mediated inhibition of oligodendrocyte precursor differentiation can be overcome by pharmacological modulation of Fyn-RhoA and protein kinase C signalling. Brain 2009, 132, 465-481. [CrossRef]

25. Jeon, S.-B.; Yoon, H.J.; Park, S.-H.; Kim, I.-H.; Park, E.J. Sulfatide, a major lipid component of myelin sheath, activates inflammatory responses as an endogenous stimulator in brain-resident immune cells. J. Immunol. 2008, 181, 8077-8087. [CrossRef]

26. Sun, X.; Wang, X.; Chen, T.; Li, T.; Cao, K.; Lu, A.; Chen, Y.; Sun, D.; Luo, J.; Fan, J.; et al. Myelin Activates FAK/Akt/NF-kB Pathways and Provokes CR3-Dependent Inflammatory Response in Murine System. PLoS ONE 2010, 5, e9380. [CrossRef]

27. Pinteaux-Jones, F.; Sevastou, I.G.; Fry, V.A.H.; Heales, S.; Baker, D.; Pocock, J.M. Myelin-induced microglial neurotoxicity can be controlled by microglial metabotropic glutamate receptors. J. Neurochem. 2008, 106, 442-454. [CrossRef]

28. Geoffroy, C.G.; Zheng, B. Myelin-associated inhibitors in axonal growth after CNS injury. Curr. Opin. Neurobiol. 2014, 27, 31-38. [CrossRef]

29. Boven, L.A.; Van Meurs, M.; Van Zwam, M.; Wierenga-Wolf, A.; Hintzen, R.Q.; Boot, R.G.; Aerts, J.M.; Amor, S.; Nieuwenhuis, E.E.; Laman, J.D. Myelin-laden macrophages are anti-inflammatory, consistent with foam cells in multiple sclerosis. Brain 2006, 129, 517-526. [CrossRef] [PubMed]

30. Csuka, E.; Hans, V.H.; Ammann, E.; Trentz, O.; Kossmann, T.; Morganti-Kossmann, M.C. Cell activation and inflammatory response following traumatic axonal injury in the rat. Neuroreport 2000, 11, 2587-2590. [CrossRef] [PubMed]

31. Loane, D.J.; Kumar, A.; Stoica, B.A.; Cabatbat, R.; Faden, A.I. Progressive Neurodegeneration After Experimental Brain Trauma. J. Neuropathol. Exp. Neurol. 2014, 73, 14-29. [CrossRef] [PubMed]

32. Taib, T.; Leconte, C.; Van Steenwinckel, J.; Cho, A.H.; Palmier, B.; Torsello, E.; Lai Kuen, R.; Onyeomah, S.; Ecomard, K.; Benedetto, C.; et al. Neuroinflammation, myelin and behavior: Temporal patterns following mild traumatic brain injury in mice. PLoS ONE 2017, 12, e0184811. [CrossRef] [PubMed]

33. Jin, X.; Ishii, H.; Bai, Z.; Itokazu, T.; Yamashita, T. Temporal changes in cell marker expression and cellular infiltration in a controlled cortical impact model in adult male C57BL/ 6 mice. PLoS ONE 2012, 7, e41892. [CrossRef] [PubMed]

34. Turtzo, L.C.; Lescher, J.; Janes, L.; Dean, D.D.; Budde, M.D.; Frank, J.A. Macrophagic and microglial responses after focal traumatic brain injury in the female rat. J. Neuroinflammation 2014, 11, 82. [CrossRef]

35. Morganti, J.M.; Riparip, L.-K.; Rosi, S. Call Off the Dog(ma): M1/M2 Polarization Is Concurrent following Traumatic Brain Injury. PLoS ONE 2016, 11, e0148001. [CrossRef]

36. Xu, H.; Wang, Z.; Li, J.; Wu, H.; Peng, Y.; Fan, L.; Chen, J.; Gu, C.; Yan, F.; Wang, L.; et al. The Polarization States of Microglia in TBI: A New Paradigm for Pharmacological Intervention. Neural Plast. 2017, 2017, 5405104. [CrossRef] [PubMed]

37. Abbott, N.J.; Rönnbäck, L.; Hansson, E. Astrocyte-endothelial interactions at the blood-brain barrier. Nat. Rev. Neurosci. 2006, 7, 41-53. [CrossRef] [PubMed]

38. Burda, J.E.; Bernstein, A.M.; Sofroniew, M. V Astrocyte roles in traumatic brain injury. Exp. Neurol. 2016, 275 Pt 3, 305-315. [CrossRef]

39. Sofroniew, M.V.; Vinters, H.V. Astrocytes: Biology and pathology. Acta Neuropathol. 2010, 119, 7-35. [CrossRef]

40. Pekny, M.; Pekna, M. Astrocyte Reactivity and Reactive Astrogliosis: Costs and Benefits. Physiol. Rev. 2014, 94, 1077-1098. [CrossRef]

41. Sofroniew, M.V. Astrocyte barriers to neurotoxic inflammation. Nat. Rev. Neurosci. 2015, 16, 249-263. [CrossRef] 
42. Liddelow, S.A.; Guttenplan, K.A.; Clarke, L.E.; Bennett, F.C.; Bohlen, C.J.; Schirmer, L.; Bennett, M.L.; Münch, A.E.; Chung, W.-S.; Peterson, T.C.; et al. Neurotoxic reactive astrocytes are induced by activated microglia. Nature 2017, 541, 481-487. [CrossRef]

43. Clark, D.P.Q.; Perreau, V.M.; Shultz, S.R.; Brady, R.D.; Lei, E.; Dixit, S.; Taylor, J.M.; Beart, P.M.; Boon, W.C. Inflammation in Traumatic Brain Injury: Roles for Toxic A1 Astrocytes and Microglial-Astrocytic Crosstalk. Neurochem. Res. 2019, 44, 1410-1424. [CrossRef]

44. Escartin, C.; Galea, E.; Lakatos, A.; O'Callaghan, J.P.; Petzold, G.C.; Serrano-Pozo, A.; Steinhäuser, C.; Volterra, A.; Carmignoto, G.; Agarwal, A.; et al. Reactive astrocyte nomenclature, definitions, and future directions. Nat. Neurosci. 2021, 24, 312-325. [CrossRef] [PubMed]

45. Morganti-Kossmann, M.C.; Satgunaseelan, L.; Bye, N.; Kossmann, T. Modulation of immune response by head injury. Injury 2007, 38, 1392-1400. [CrossRef] [PubMed]

46. Susarla, B.T.S.; Villapol, S.; Yi, J.-H.; Geller, H.M.; Symes, A.J. Temporal Patterns of Cortical Proliferation of Glial Cell Populations after Traumatic Brain Injury in Mice. ASN Neuro 2014, 6, AN20130034. [CrossRef] [PubMed]

47. Villapol, S.; Byrnes, K.R.; Symes, A.J. Temporal Dynamics of Cerebral Blood Flow, Cortical Damage, Apoptosis, Astrocyteâ€"Vasculature Interaction and Astrogliosis in the Pericontusional Region after Traumatic Brain Injury. Front. Neurol. 2014, 5, 82. [CrossRef]

48. Kumar, A.; Loane, D.J. Neuroinflammation after traumatic brain injury: Opportunities for therapeutic intervention. Brain. Behav. Immun. 2012, 26, 1191-1201. [CrossRef]

49. Ziebell, J.M.; Morganti-Kossmann, M.C. Involvement of pro- and anti-inflammatory cytokines and chemokines in the pathophysiology of traumatic brain injury. Neurotherapeutics 2010, 7, 22-30. [CrossRef]

50. Chiu, C.-C.; Liao, Y.-E.; Yang, L.-Y.; Wang, J.-Y.; Tweedie, D.; Karnati, H.K.; Greig, N.H.; Wang, J.-Y. Neuroinflammation in animal models of traumatic brain injury. J. Neurosci. Methods 2016, 272, 38-49. [CrossRef]

51. Rodney, T.; Osier, N.; Gill, J. Pro- and anti-inflammatory biomarkers and traumatic brain injury outcomes: A review. Cytokine 2018, 110, 248-256. [CrossRef]

52. Woodcock, T.; Morganti-Kossmann, M.C. The role of markers of inflammation in traumatic brain injury. Front. Neurol. 2013, 4, 18. [CrossRef] [PubMed]

53. Fan, L.; Young, P.R.; Barone, F.C.; Feuerstein, G.Z.; Smith, D.H.; McIntosh, T.K. Experimental brain injury induces expression of interleukin-1 $\beta$ mRNA in the rat brain. Mol. Brain Res. 1995, 30, 125-130. [CrossRef]

54. Kinoshita, K.; Chatzipanteli, K.; Vitarbo, E.; Truettner, J.S.; Alonso, O.F.; Dietrich, W.D. Interleukin-1 $\beta$ Messenger Ribonucleic Acid and Protein Levels after Fluid-Percussion Brain Injury in Rats: Importance of Injury Severity and Brain Temperature. Neurosurgery 2002, 51, 195-203. [CrossRef] [PubMed]

55. Lu, K.-T.; Wang, Y.-W.; Wo, Y.-Y.P.; Yang, Y.-L. Extracellular signal-regulated kinase-mediated IL-1-induced cortical neuron damage during traumatic brain injury. Neurosci. Lett. 2005, 386, 40-45. [CrossRef] [PubMed]

56. Lu, K.-T.; Wang, Y.-W.; Yang, J.-T.; Yang, Y.-L.; Chen, H.-I. Effect of Interleukin-1 on Traumatic Brain Injury-Induced Damage to Hippocampal Neurons. J. Neurotrauma 2005, 22, 885-895. [CrossRef] [PubMed]

57. Kamm, K.; VanderKolk, W.; Lawrence, C.; Jonker, M.; Davis, A.T. The Effect of Traumatic Brain Injury Upon the Concentration and Expression of Interleukin-1?? and Interleukin-10 in the Rat. J. Trauma INJ Infect. Crit. Care 2006, 60, 152-157. [CrossRef] [PubMed]

58. Taupin, V.; Toulmond, S.; Serrano, A.; Benavides, J.; Zavala, F. Increase in IL-6, IL-1 and TNF levels in rat brain following traumatic lesion. Influence of pre- and post-traumatic treatment with Ro5 4864, a peripheral-type (p site) benzodiazepine ligand. J. Neuroimmunol. 1993, 42, 177-185. [CrossRef]

59. Shohami, E.; Novikov, M.; Bass, R.; Yamin, A.; Gallily, R. Closed Head Injury Triggers Early Production of TNF $\alpha$ and IL-6 by Brain Tissue. J. Cereb. Blood Flow Metab. 1994, 14, 615-619. [CrossRef]

60. Fan, L.; Young, P.R.; Barone, F.C.; Feuerstein, G.Z.; Smith, D.H.; McIntosh, T.K. Experimental brain injury induces differential expression of tumor necrosis factor- $\alpha$ mRNA in the CNS. Mol. Brain Res. 1996, 36, 287-291. [CrossRef]

61. Knoblach, S.M.; Fan, L.; Faden, A.I. Early neuronal expression of tumor necrosis factor-alpha after experimental brain injury contributes to neurological impairment. J. Neuroimmunol. 1999, 95, 115-125. [CrossRef]

62. Dalgard, C.L.; Cole, J.T.; Kean, W.S.; Lucky, J.J.; Sukumar, G.; McMullen, D.C.; Pollard, H.B.; Watson, W.D. The cytokine temporal profile in rat cortex after controlled cortical impact. Front. Mol. Neurosci. 2012, 5, 6. [CrossRef]

63. Woodroofe, M.N.; Sarna, G.S.; Wadhwa, M.; Hayes, G.M.; Loughlin, A.J.; Tinker, A.; Cuzner, M.L. Detection of interleukin-1 and interleukin-6 in adult rat brain, following mechanical injury, by in vivo microdialysis: Evidence of a role for microglia in cytokine production. J. Neuroimmunol. 1991, 33, 227-236. [CrossRef]

64. Maegele, M.; Sauerland, S.; Bouillon, B.; Schäfer, U.; Trübel, H.; Riess, P.; Neugebauer, E.A.M. Differential immunoresponses following experimental traumatic brain injury, bone fracture and "two-hit"-combined neurotrauma. Inflamm. Res. 2007, 56, 318-323. [CrossRef]

65. Williams, A.J.; Wei, H.H.; Dave, J.R.; Tortella, F.C. Acute and delayed neuroinflammatory response following experimental penetrating ballistic brain injury in the rat. J. Neuroinflammation 2007, 4, 17. [CrossRef]

66. Ziebell, J.M.; Bye, N.; Semple, B.D.; Kossmann, T.; Morganti-Kossmann, M.C. Attenuated neurological deficit, cell death and lesion volume in Fas-mutant mice is associated with altered neuroinflammation following traumatic brain injury. Brain Res. 2011, 1414, 94-105. [CrossRef] [PubMed] 
67. Weckbach, S.; Perl, M.; Heiland, T.; Braumüller, S.; Stahel, P.F.; Flierl, M.A.; Ignatius, A.; Gebhard, F.; Huber-Lang, M. A New Experimental Polytrauma Model in Rats: Molecular Characterization of the Early Inflammatory Response. Mediators Inflamm. 2012, 2012, 890816. [CrossRef] [PubMed]

68. Knoblach, S.M.; Faden, A.I. Interleukin-10 Improves Outcome and Alters Proinflammatory Cytokine Expression after Experimental Traumatic Brain Injury. Exp. Neurol. 1998, 153, 143-151. [CrossRef] [PubMed]

69. Rhodes, J. Peripheral immune cells in the pathology of traumatic brain injury? Curr. Opin. Crit. Care 2011, 17, 122-130. [CrossRef]

70. Corps, K.N.; Roth, T.L.; McGavern, D.B. Inflammation and Neuroprotection in Traumatic Brain Injury. JAMA Neurol. 2015, 72, 355. [CrossRef]

71. Fusco, R.; Gugliandolo, E.; Siracusa, R.; Scuto, M.; Cordaro, M.; D’amico, R.; Evangelista, M.; Peli, A.; Peritore, A.F.; Impellizzeri, D.; et al. Formyl peptide receptor 1 signaling in acute inflammation and neural differentiation induced by traumatic brain injury. Biology 2020, 9, 238. [CrossRef]

72. Morganti-Kossmann, M.C.; Rancan, M.; Stahel, P.F.; Kossmann, T. Inflammatory response in acute traumatic brain injury: A double-edged sword. Curr. Opin. Crit. Care 2002, 8, 101-105. [CrossRef]

73. Lozano, D.; Gonzales-Portillo, G.S.; Acosta, S.; de la Pena, I.; Tajiri, N.; Kaneko, Y.; Borlongan, C. V Neuroinflammatory responses to traumatic brain injury: Etiology, clinical consequences, and therapeutic opportunities. Neuropsychiatr. Dis. Treat. 2015, 11, 97-106. [CrossRef]

74. Kelley, B.J.; Lifshitz, J.; Povlishock, J.T. Neuroinflammatory Responses after Experimental Diffuse Traumatic Brain Injury. J. Neuropathol. Exp. Neurol. 2007, 66, 989-1001. [CrossRef]

75. Johnson, V.E.; Stewart, J.E.; Begbie, F.D.; Trojanowski, J.Q.; Smith, D.H.; Stewart, W. Inflammation and white matter degeneration persist for years after a single traumatic brain injury. Brain 2013, 136, 28-42. [CrossRef] [PubMed]

76. Aungst, S.L.; Kabadi, S.V.; Thompson, S.M.; Stoica, B.A.; Faden, A.I. Repeated Mild Traumatic Brain Injury Causes Chronic Neuroinflammation, Changes in Hippocampal Synaptic Plasticity, and Associated Cognitive Deficits. J. Cereb. Blood Flow Metab. 2014, 34, 1223-1232. [CrossRef]

77. Faden, A.I.; Loane, D.J. Chronic Neurodegeneration after Traumatic Brain Injury: Alzheimer Disease, Chronic Traumatic Encephalopathy, or Persistent Neuroinflammation? Neurotherapeutics 2015, 12, 143-150. [CrossRef] [PubMed]

78. Smith, D.H.; Chen, X.H.; Pierce, J.E.; Wolf, J.A.; Trojanowski, J.Q.; Graham, D.I.; McIntosh, T.K. Progressive atrophy and neuron death for one year following brain trauma in the rat. J. Neurotrauma 1997, 14, 715-727. [CrossRef]

79. Ajao, D.O.; Pop, V.; Kamper, J.E.; Adami, A.; Rudobeck, E.; Huang, L.; Vlkolinsky, R.; Hartman, R.E.; Ashwal, S.; Obenaus, A.; et al. Traumatic Brain Injury in Young Rats Leads to Progressive Behavioral Deficits Coincident with Altered Tissue Properties in Adulthood. J. Neurotrauma 2012, 29, 2060-2074. [CrossRef]

80. Donovan, V.; Kim, C.; Anugerah, A.K.; Coats, J.S.; Oyoyo, U.; Pardo, A.C.; Obenaus, A. Repeated mild traumatic brain injury results in long-term white-matter disruption. J. Cereb. Blood Flow Metab. 2014, 34, 715-723. [CrossRef] [PubMed]

81. Laitinen, T.; Sierra, A.; Bolkvadze, T.; Pitkänen, A.; Gröhn, O. Diffusion tensor imaging detects chronic microstructural changes in white and gray matter after traumatic brain injury in rat. Front. Neurosci. 2015, 9, 128. [CrossRef] [PubMed]

82. Harris, N.G.; Verley, D.R.; Gutman, B.A.; Sutton, R.L. Bi-directional changes in fractional anisotropy after experiment TBI: Disorganization and reorganization? Neuroimage 2016, 133, 129-143. [CrossRef]

83. Flygt, J.; Djupsjö, A.; Lenne, F.; Marklund, N. Myelin loss and oligodendrocyte pathology in white matter tracts following traumatic brain injury in the rat. Eur. J. Neurosci. 2013, 38, 2153-2165. [CrossRef]

84. Reeves, T.; Phillips, L.; Povlishock, J. Myelinated and unmyelinated axons of the corpus callosum differ in vulnerability and functional recovery following traumatic brain injury. Exp. Neurol. 2005, 196, 126-137. [CrossRef] [PubMed]

85. Mierzwa, A.J.; Marion, C.M.; Sullivan, G.M.; McDaniel, D.P.; Armstrong, R.C. Components of myelin damage and repair in the progression of white matter pathology after mild traumatic brain injury. J. Neuropathol. Exp. Neurol. 2015, 74, 218-232. [CrossRef]

86. Bradl, M.; Lassmann, H. Oligodendrocytes: Biology and pathology. Acta Neuropathol. 2010, 119, 37-53. [CrossRef] [PubMed]

87. Shi, H.; Hu, X.; Leak, R.K.; Shi, Y.; An, C.; Suenaga, J.; Chen, J.; Gao, Y. Demyelination as a rational therapeutic target for ischemic or traumatic brain injury. Exp. Neurol. 2015, 272, 17-25. [CrossRef] [PubMed]

88. Israelsson, C.; Flygt, J.; Åstrand, E.; Kiwanuka, O.; Bengtsson, H.; Marklund, N. Altered expression of myelin-associated inhibitors and their receptors after traumatic brain injury in the mouse. Restor. Neurol. Neurosci. 2014, 32, 717-731. [CrossRef] [PubMed]

89. Yang, X.F.; Wang, H.; Wen, L. From myelin debris to inflammatory responses: A vicious circle in diffuse axonal injury. Med. Hypotheses 2011, 77, 60-62. [CrossRef] [PubMed]

90. Wang, X.; Cao, K.; Sun, X.; Chen, Y.; Duan, Z.; Sun, L.; Guo, L.; Bai, P.; Sun, D.; Fan, J.; et al. Macrophages in spinal cord injury: Phenotypic and functional change from exposure to myelin debris. Glia 2015, 63, 635-651. [CrossRef]

91. Barbacci, D.C.; Roux, A.; Muller, L.; Jackson, S.N.; Post, J.; Baldwin, K.; Hoffer, B.; Balaban, C.D.; Schultz, J.A.; Gouty, S.; et al. Mass Spectrometric Imaging of Ceramide Biomarkers Tracks Therapeutic Response in Traumatic Brain Injury. ACS Chem. Neurosci. 2017, 8, 2266-2274. [CrossRef]

92. Roux, A.; Muller, L.; Jackson, S.N.; Post, J.; Baldwin, K.; Hoffer, B.; Balaban, C.D.; Barbacci, D.; Schultz, J.A.; Gouty, S.; et al. Mass spectrometry imaging of rat brain lipid profile changes over time following traumatic brain injury. J. Neurosci. Methods 2016, 272, 19-32. [CrossRef] 
93. Woods, A.S.; Colsch, B.; Jackson, S.N.; Post, J.; Baldwin, K.; Roux, A.; Hoffer, B.; Cox, B.M.; Hoffer, M.; Rubovitch, V.; et al. Gangliosides and ceramides change in a mouse model of blast induced traumatic brain injury. ACS Chem. Neurosci. 2013, 4, 594-600. [CrossRef]

94. Abdullah, L.; Evans, J.E.; Ferguson, S.; Mouzon, B.; Montague, H.; Reed, J.; Crynen, G.; Emmerich, T.; Crocker, M.; Pelot, R.; et al. Lipidomic analyses identify injury-specific phospholipid changes 3 mo after traumatic brain injury. FASEB J. 2014, 28, 5311-5321. [CrossRef] [PubMed]

95. Emmerich, T.; Abdullah, L.; Crynen, G.; Dretsch, M.; Evans, J.; Ait-Ghezala, G.; Reed, J.; Montague, H.; Chaytow, H.; Mathura, V.; et al. Plasma Lipidomic Profiling in a Military Population of Mild Traumatic Brain Injury and Post-Traumatic Stress Disorder with Apolipoprotein E $\in 4$-Dependent Effect. J. Neurotrauma 2016, 33, 1331-1348. [CrossRef]

96. Lerouet, D.; Taib, T.; Auzeil, N.; Regazzetti, A.; Coqueran, B.; Laprévote, O.; Marchand-Leroux, C.; Besson, V. Lipid profile of corpus callosum: A witness of demyelination after traumatic brain injury. GLIA 2017, 65, E103-E578. [CrossRef]

97. Sheth, S.A.; Iavarone, A.T.; Liebeskind, D.S.; Won, S.J.; Swanson, R.A. Targeted Lipid Profiling Discovers Plasma Biomarkers of Acute Brain Injury. PLoS ONE 2015, 10, e0129735. [CrossRef] [PubMed]

98. Lotocki, G.; Vaccari, J.d.R.; Alonso, O.; Sanchez Molano, J.; Nixon, R.; Safavi, P.; Dietrich, W.D.; Bramlett, H.M. Oligodendrocyte vulnerability following traumatic brain injury in rats. Neurosci. Lett. 2011, 499, 143-148. [CrossRef] [PubMed]

99. Miron, V.E.; Boyd, A.; Zhao, J.-W.; Yuen, T.J.; Ruckh, J.M.; Shadrach, J.L.; van Wijngaarden, P.; Wagers, A.J.; Williams, A.; Franklin, R.J.M.; et al. M2 microglia and macrophages drive oligodendrocyte differentiation during CNS remyelination. Nat. Neurosci. 2013, 16, 1211-1218. [CrossRef]

100. Bennett, R.E.; Brody, D.L. Acute Reduction of Microglia Does Not Alter Axonal Injury in a Mouse Model of Repetitive Concussive Traumatic Brain Injury. J. Neurotrauma 2014, 31, 1647-1663. [CrossRef]

101. Febinger, H.Y.; Thomasy, H.E.; Pavlova, M.N.; Ringgold, K.M.; Barf, P.R.; George, A.M.; Grillo, J.N.; Bachstetter, A.D.; Garcia, J.A.; Cardona, A.E.; et al. Time-dependent effects of CX3CR1 in a mouse model of mild traumatic brain injury. J. Neuroinflammation 2015, 12, 154. [CrossRef]

102. Semple, B.D.; Bye, N.; Rancan, M.; Ziebell, J.M.; Morganti-Kossmann, M.C. Role of CCL2 (MCP-1) in traumatic brain injury (TBI): Evidence from severe TBI patients and CCL2-/- mice. J. Cereb. Blood Flow Metab. 2010, 30, 769-782. [CrossRef]

103. Kenne, E.; Erlandsson, A.; Lindbom, L.; Hillered, L.; Clausen, F. Neutrophil depletion reduces edema formation and tissue loss following traumatic brain injury in mice. J. Neuroinflammation 2012, 9, 17. [CrossRef]

104. Morganti, J.M.; Jopson, T.D.; Liu, S.; Riparip, L.-K.; Guandique, C.K.; Gupta, N.; Ferguson, A.R.; Rosi, S. CCR2 antagonism alters brain macrophage polarization and ameliorates cognitive dysfunction induced by traumatic brain injury. J. Neurosci. 2015, 35, 748-760. [CrossRef]

105. Kharatishvili, I.; Nissinen, J.P.; McIntosh, T.K.; Pitkänen, A. A model of posttraumatic epilepsy induced by lateral fluid-percussion brain injury in rats. Neuroscience 2006, 140, 685-697. [CrossRef] [PubMed]

106. Di Sapia, R.; Moro, F.; Montanarella, M.; Iori, V.; Micotti, E.; Tolomeo, D.; Wang, K.K.W.; Vezzani, A.; Ravizza, T.; Zanier, E.R. In-depth characterization of a mouse model of post-traumatic epilepsy for biomarker and drug discovery. Acta Neuropathol. Commun. 2021, 9, 76. [CrossRef] [PubMed]

107. Vezzani, A.; Balosso, S.; Ravizza, T. Neuroinflammatory pathways as treatment targets and biomarkers in epilepsy. Nat. Rev. Neurol. 2019, 15, 459-472. [CrossRef] [PubMed]

108. Pauletti, A.; Terrone, G.; Shekh-Ahmad, T.; Salamone, A.; Ravizza, T.; Rizzi, M.; Pastore, A.; Pascente, R.; Liang, L.-P.; Villa, B.R.; et al. Targeting oxidative stress improves disease outcomes in a rat model of acquired epilepsy. Brain 2019, 142, e39. [CrossRef]

109. Noebels, J.L.; Avoli, M.; Rogawski, M.; Olsen, R.; Delgado-Escueta, A.V. “Jasper's basic mechanisms of the epilepsies” workshop. Epilepsia 2010, 51, 1-5. [CrossRef] [PubMed]

110. Arulsamy, A.; Corrigan, F.; Collins-Praino, L.E. Cognitive and neuropsychiatric impairments vary as a function of injury severity at 12 months post-experimental diffuse traumatic brain injury: Implications for dementia development. Behav. Brain Res. 2019, 365, 66-76. [CrossRef] [PubMed]

111. Leconte, C.; Benedetto, C.; Lentini, F.; Simon, K.; Ouaazizi, C.; Taib, T.; Cho, A.; Plotkine, M.; Mongeau, R.; Marchand-Leroux, C.; et al. Histological and Behavioral Evaluation after Traumatic Brain Injury in Mice: A Ten Months Follow-Up Study. J. Neurotrauma 2020, 37, 1342-1357. [CrossRef] [PubMed]

112. Gold, E.M.; Su, D.; López-Velázquez, L.; Haus, D.L.; Perez, H.; Lacuesta, G.A.; Anderson, A.J.; Cummings, B.J. Functional assessment of long-term deficits in rodent models of traumatic brain injury. Regen. Med. 2013, 8, 483-516. [CrossRef]

113. Cheng, J.P.; Shaw, K.E.; Monaco, C.M.; Hoffman, A.N.; Sozda, C.N.; Olsen, A.S.; Kline, A.E. A relatively brief exposure to environmental enrichment after experimental traumatic brain injury confers long-term cognitive benefits. J. Neurotrauma 2012, 29, 2684-2688. [CrossRef]

114. Zhao, Z.; Loane, D.J.; Murray, M.G.; Stoica, B.A.; Faden, A.I. Comparing the predictive value of multiple cognitive, affective, and motor tasks after rodent traumatic brain injury. J. Neurotrauma 2012, 29, 2475-2489. [CrossRef]

115. Shear, D.A.; Tate, C.C.; Tate, M.C.; Archer, D.R.; Laplaca, M.C.; Stein, D.G.; Dunbar, G.L. Stem cell survival and functional outcome after traumatic brain injury is dependent on transplant timing and location. Restor. Neurol. Neurosci. 2011, 29, 215-225. [CrossRef] 
116. Dixon, C.E.; Kochanek, P.M.; Yan, H.Q.; Schiding, J.K.; Griffith, R.G.; Baum, E.; Marion, D.W.; DeKosky, S.T. One-year study of spatial memory performance, brain morphology, and cholinergic markers after moderate controlled cortical impact in rats. $J$. Neurotrauma 1999, 16, 109-122. [CrossRef]

117. Hallam, T.M.; Floyd, C.L.; Folkerts, M.M.; Lee, L.L.; Gong, Q.Z.; Lyeth, B.G.; Paul Muizelaar, J.; Berman, R.F. Comparison of behavioral deficits and acute neuronal degeneration in rat lateral fluid percussion and weight-drop brain injury models. $J$. Neurotrauma 2004, 21, 521-539. [CrossRef]

118. Edut, S.; Rubovitch, V.; Schreiber, S.; Pick, C.G. The intriguing effects of ecstasy (MDMA) on cognitive function in mice subjected to a minimal traumatic brain injury (mTBI). Psychopharmacology 2011, 214, 877-889. [CrossRef] [PubMed]

119. Kosari-Nasab, M.; Shokouhi, G.; Ghorbanihaghjo, A.; Abbasi, M.M.; Salari, A.A. Anxiolytic- and antidepressant-like effects of Silymarin compared to diazepam and fluoxetine in a mouse model of mild traumatic brain injury. Toxicol. Appl. Pharmacol. 2018, 338, 159-173. [CrossRef]

120. Milman, A.; Rosenberg, A.; Weizman, R.; Pick, C.G. Mild traumatic brain injury induces persistent cognitive deficits and behavioral disturbances in mice. J. Neurotrauma 2005, 22, 1003-1010. [CrossRef] [PubMed]

121. Geeraerts, T.; Velly, L.; Abdennour, L.; Asehnoune, K.; Audibert, G.; Bouzat, P.; Bruder, N.; Carrillon, R.; Cottenceau, V.; Cotton, F.; et al. Management of severe traumatic brain injury (first 24 hours). Anaesth. Crit. Care Pain Med. 2018, 37, 171-186. [CrossRef] [PubMed]

122. Jarrahi, A.; Braun, M.; Ahluwalia, M.; Gupta, R.V.; Wilson, M.; Munie, S.; Ahluwalia, P.; Vender, J.R.; Vale, F.L.; Dhandapani, K.M.; et al. Revisiting traumatic brain injury: From molecular mechanisms to therapeutic interventions. Biomedicines 2020, 8, 389. [CrossRef]

123. Crupi, R.; Cordaro, M.; Cuzzocrea, S.; Impellizzeri, D. Management of traumatic brain injury: From present to future. Antioxidants 2020, 9, 297. [CrossRef] [PubMed]

124. Lerouet, D.; Marchand-Leroux, C.; Besson, V.C. Neuropharmacology in traumatic brain injury: From preclinical to clinical neuroprotection? Fundam. Clin. Pharmacol. 2021, 35, 524-538. [CrossRef] [PubMed]

125. Newell, E.; Shellington, D.K.; Simon, D.W.; Bell, M.J.; Kochanek, P.M.; Feldman, K.; Bayir, H.; Aneja, R.K.; Carcillo, J.A.; Clark, R.S.B. Cerebrospinal fluid markers of macrophage and lymphocyte activation after traumatic brain injury in children. Pediatr. Crit. Care Med. 2015, 16, 549-557. [CrossRef] [PubMed]

126. Mollayeva, T.; Mollayeva, S.; Colantonio, A. Traumatic brain injury: Sex, gender and intersecting vulnerabilities. Nat. Rev. Neurol. 2018, 14, 711-722. [CrossRef] [PubMed]

127. Ziebell, J.M.; Rowe, R.K.; Muccigrosso, M.M.; Reddaway, J.T.; Adelson, P.D.; Godbout, J.P.; Lifshitz, J. Aging with a traumatic brain injury: Could behavioral morbidities and endocrine symptoms be influenced by microglial priming? Brain. Behav. Immun. 2017, 59, 1-7. [CrossRef] [PubMed]

128. Stratoulias, V.; Venero, J.L.; Tremblay, M.; Joseph, B. Microglial subtypes: Diversity within the microglial community. EMBO J. 2019, 38, e101997. [CrossRef]

129. Cordaro, M.; D'Amico, R.; Morabito, R.; Fusco, R.; Siracusa, R.; Peritore, A.F.; Impellizzeri, D.; Genovese, T.; Crupi, R.; Gugliandolo, E.; et al. Physiological and Biochemical Changes in NRF2 Pathway in Aged Animals Subjected to Brain Injury. Cell. Physiol. Biochem. 2021, 55, 160-179. [CrossRef]

130. Simon, D.W.; McGeachy, M.J.; Bayır, H.; Clark, R.S.B.; Loane, D.J.; Kochanek, P.M. The far-reaching scope of neuroinflammation after traumatic brain injury. Nat. Rev. Neurol. 2017, 13, 572. [CrossRef] [PubMed]

131. Zhang, Z.; Saraswati, M.; Koehler, R.C.; Robertson, C.; Kannan, S. A New Rabbit Model of Pediatric Traumatic Brain Injury. J. Neurotrauma 2015, 32, 1369-1379. [CrossRef]

132. Dobbing, J. The later growth of the brain and its vulnerability. Pediatrics 1974, 53, 2-6. [CrossRef]

133. Lagercrantz, H.; Ringstedt, T. Organization of the neuronal circuits in the central nervous system during development. Acta Paediatr. 2007, 90, 707-715. [CrossRef]

134. Rice, D.; Barone, S. Critical periods of vulnerability for the developing nervous system: Evidence from humans and animal models. Environ. Health Perspect. 2000, 108, 511-533. [CrossRef]

135. Romijn, H.J.; Hofman, M.A.; Gramsbergen, A. At what age is the developing cerebral cortex of the rat comparable to that of the full-term newborn human baby? Early Hum. Dev. 1991, 26, 61-67. [CrossRef]

136. Semple, B.D.; Blomgren, K.; Gimlin, K.; Ferriero, D.M.; Noble-Haeusslein, L.J. Brain development in rodents and humans: Identifying benchmarks of maturation and vulnerability to injury across species. Prog. Neurobiol. 2013, 106-107, 1-16. [CrossRef]

137. Nehlig, A.; de Vasconcelos, A.P.; Boyet, S. Quantitative autoradiographic measurement of local cerebral glucose utilization in freely moving rats during postnatal development. J. Neurosci. 1988, 8, 2321-2333. [CrossRef]

138. Prins, M.L.; Hales, A.; Reger, M.; Giza, C.C.; Hovda, D.A. Repeat traumatic brain injury in the juvenile rat is associated with increased axonal injury and cognitive impairments. Dev. Neurosci. 2010, 32, 510-518. [CrossRef]

139. Kaindl, A.M.; Zabel, C.; Stefovska, V.; Lehnert, R.; Sifringer, M.; Klose, J.; Ikonomidou, C. Subacute proteome changes following traumatic injury of the developing brain: Implications for a dysregulation of neuronal migration and neurite arborization. Proteom. Clin. Appl. 2007, 1, 640-649. [CrossRef] [PubMed]

140. Pohl, D.; Bittigau, P.; Ishimaru, M.J.; Stadthaus, D.; Hübner, C.; Olney, J.W.; Turski, L.; Ikonomidou, C. N-Methyl-D-aspartate antagonists and apoptotic cell death triggered by head trauma in developing rat brain. Proc. Natl. Acad. Sci. USA 1999, 96, 2508-2513. [CrossRef] [PubMed] 
141. Ikonomidou, C.; Qin, Y.; Labruyere, J.; Kirby, C.; Olney, J.W. Prevention of Trauma-Induced Neurodegeneration in Infant Rat Brain. Pediatr. Res. 1996, 39, 1020-1027. [CrossRef] [PubMed]

142. Haldipur, P.; Dupuis, N.; Degos, V.; Moniaux, N.; Chhor, V.; Rasika, S.; Schwendimann, L.; le Charpentier, T.; Rougier, E.; Amouyal, P.; et al. HIP/PAP prevents excitotoxic neuronal death and promotes plasticity. Ann. Clin. Transl. Neurol. 2014, 1, 739-754. [CrossRef]

143. Moretti, R.; Chhor, V.; Bettati, D.; Banino, E.; De Lucia, S.; Le Charpentier, T.; Lebon, S.; Schwendimann, L.; Pansiot, J.; Rasika, S.; et al. Contribution of mast cells to injury mechanisms in a mouse model of pediatric traumatic brain injury. J. Neurosci. Res. 2016, 94, 1546-1560. [CrossRef]

144. Chhor, V.; Moretti, R.; Le Charpentier, T.; Sigaut, S.; Lebon, S.; Schwendimann, L.; Oré, M.-V.; Zuiani, C.; Milan, V.; Josserand, J.; et al. Role of microglia in a mouse model of paediatric traumatic brain injury. Brain. Behav. Immun. 2017, 63, 197-209. [CrossRef]

145. Martin, L.J.; Wong, M.; Hanaford, A. Neonatal brain injury and genetic causes of adult-onset neurodegenerative disease in mice interact with effects on acute and late outcomes. Front. Neurol. 2019, 10, 635. [CrossRef] [PubMed]

146. Cigel, A.; Sayin, O.; Gurgen, S.G.; Sonmez, A. Long term neuroprotective effects of acute single dose MK-801treatment against traumatic brain injury in immature rats. Neuropeptides 2021, 88, 102161. [CrossRef]

147. Bittigau, P.; Sifringer, M.; Pohl, D.; Stadthaus, D.; Ishimaru, M.; Shimizu, H.; Ikeda, M.; Lang, D.; Speer, A.; Olney, J.W.; et al. Apoptotic neurodegeneration following trauma is markedly enhanced in the immature brain. Ann. Neurol. 1999, 45, 724-735. [CrossRef]

148. Lengel, D.; Huh, J.W.; Barson, J.R.; Raghupathi, R. Progesterone treatment following traumatic brain injury in the 11-day-old rat attenuates cognitive deficits and neuronal hyperexcitability in adolescence. Exp. Neurol. 2020, 330, 113329. [CrossRef] [PubMed]

149. Raghupathi, R.; Huh, J.W. Diffuse Brain Injury in the Immature Rat: Evidence for an Age-at-Injury Effect on Cognitive Function and Histopathologic Damage. J. Neurotrauma 2007, 24, 1596-1608. [CrossRef] [PubMed]

150. Hanlon, L.A.; Raghupathi, R.; Huh, J.W. Depletion of microglia immediately following traumatic brain injury in the pediatric rat: Implications for cellular and behavioral pathology. Exp. Neurol. 2019, 316, 39-51. [CrossRef] [PubMed]

151. Runyan, A.; Lengel, D.; Huh, J.W.; Barson, J.R.; Raghupathi, R. Intranasal administration of oxytocin attenuates social recognition deficits and increases prefrontal cortex inhibitory postsynaptic currents following traumatic brain injury. eNeuro 2021, 8, 1-14. [CrossRef] [PubMed]

152. Kaindl, A.M.; Degos, V.; Peineau, S.; Gouadon, E.; Chhor, V.; Loron, G.; Le Charpentier, T.; Josserand, J.; Ali, C.; Vivien, D.; et al. Activation of microglial N-methyl-D-aspartate receptors triggers inflammation and neuronal cell death in the developing and mature brain. Ann. Neurol. 2012, 72, 536-549. [CrossRef]

153. Garrido-Mesa, N.; Zarzuelo, A.; Gálvez, J. Minocycline: Far beyond an antibiotic. Br. J. Pharmacol. 2013, 169, 337-352. [CrossRef] [PubMed]

154. Zhang, T.; Finn, D.F.; Barlow, J.W.; Walsh, J.J. Mast cell stabilisers. Eur. J. Pharmacol. 2016, 778, 158-168. [CrossRef]

155. Hendrix, S.; Kramer, P.; Pehl, D.; Warnke, K.; Boato, F.; Nelissen, S.; Lemmens, E.; Pejler, G.; Metz, M.; Siebenhaar, F.; et al. Mast cells protect from post-traumatic brain inflammation by the mast cell-specific chymase mouse mast cell protease-4. FASEB J. 2013, 27, 920-929. [CrossRef]

156. Bjelke, B.; Seiger, A. Morphological distribution of MBP-like immunoreactivity in the brain during development. Int. J. Dev. Neurosci. 1989, 7, 145-164. [CrossRef]

157. Akiyama, K.; Ichinose, S.; Omori, A.; Sakurai, Y.; Asou, H. Study of expression of myelin basic proteins (MBPs) in developing rat brain using a novel antibody reacting with four major isoforms of MBP. J. Neurosci. Res. 2002, 68, 19-28. [CrossRef]

158. Rodriguez-Grande, B.; Obenaus, A.; Ichkova, A.; Aussudre, J.; Bessy, T.; Barse, E.; Hiba, B.; Catheline, G.; Barrière, G.; Badaut, J. Gliovascular changes precede white matter damage and long-term disorders in juvenile mild closed head injury. Glia 2018, 66, 1663-1677. [CrossRef]

159. Clément, T.; Lee, J.B.; Ichkova, A.; Rodriguez-Grande, B.; Fournier, M.; Aussudre, J.; Ogier, M.; Haddad, E.; Canini, F.; Koehl, M.; et al. Juvenile mild traumatic brain injury elicits distinct spatiotemporal astrocyte responses. Glia 2020, 68, 528-542. [CrossRef]

160. Karelina, K.; Nicholson, S.; Weil, Z.M. Minocycline blocks traumatic brain injury-induced alcohol consumption and nucleus accumbens inflammation in adolescent male mice. Brain. Behav. Immun. 2018, 69, 532-539. [CrossRef] [PubMed]

161. Webster, K.M.; Sun, M.; Crack, P.J.; O’Brien, T.J.; Shultz, S.R.; Semple, B.D. Age-dependent release of high-mobility group box protein-1 and cellular neuroinflammation after traumatic brain injury in mice. J. Comp. Neurol. 2019, 527, 1102-1117. [CrossRef] [PubMed]

162. Fletcher, J.L.; Dill, L.K.; Wood, R.J.; Wang, S.; Robertson, K.; Murray, S.S.; Zamani, A.; Semple, B.D. Acute treatment with TrkB agonist LM22A-4 confers neuroprotection and preserves myelin integrity in a mouse model of pediatric traumatic brain injury. Exp. Neurol. 2021, 339, 113652. [CrossRef]

163. Sharma, R.; Zamani, A.; Dill, L.K.; Sun, M.; Chu, E.; Robinson, M.J.; O’Brien, T.J.; Shultz, S.R.; Semple, B.D. A systemic immune challenge to model hospital-acquired infections independently regulates immune responses after pediatric traumatic brain injury. J. Neuroinflammation 2021, 18, 72. [CrossRef] [PubMed]

164. Semple, B.D.; Sadjadi, R.; Carlson, J.; Chen, Y.; Xu, D.; Ferriero, D.M.; Noble-Haeusslein, L.J. Long-Term Anesthetic-Dependent Hypoactivity after Repetitive Mild Traumatic Brain Injuries in Adolescent Mice. Dev. Neurosci. 2016, 38, 220-238. [CrossRef] 
165. Merkel, S.F.; Andrews, A.M.; Lutton, E.M.; Razmpour, R.; Cannella, L.A.; Ramirez, S.H. Dexamethasone Attenuates the Enhanced Rewarding Effects of Cocaine Following Experimental Traumatic Brain Injury. Cell Transplant. 2017, 26, 1178-1192. [CrossRef] [PubMed]

166. Merkel, S.F.; Razmpour, R.; Lutton, E.M.; Tallarida, C.S.; Heldt, N.A.; Cannella, L.A.; Persidsky, Y.; Rawls, S.M.; Ramirez, S.H. Adolescent Traumatic Brain Injury Induces Chronic Mesolimbic Neuroinflammation with Concurrent Enhancement in the Rewarding Effects of Cocaine in Mice during Adulthood. J. Neurotrauma 2017, 34, 165-181. [CrossRef] [PubMed]

167. Hetzer, S.M.; Guilhaume-Correa, F.; Day, D.; Bedolla, A.; Evanson, N.K. Traumatic Optic Neuropathy Is Associated with Visual Impairment, Neurodegeneration, and Endoplasmic Reticulum Stress in Adolescent Mice. Cells 2021, 10, 996. [CrossRef] [PubMed]

168. Cannella, L.A.; Andrews, A.M.; Tran, F.; Razmpour, R.; McGary, H.; Collie, C.; Tsegaye, T.; Maynard, M.; Kaufman, M.J.; Rawls, S.M.; et al. Experimental traumatic brain injury during adolescence enhances cocaine rewarding efficacy and dysregulates dopamine and neuroimmune systems in brain reward substrates. J. Neurotrauma 2020, 37, 27-42. [CrossRef]

169. Zhang, Z.; Rasmussen, L.; Saraswati, M.; Koehler, R.C.; Robertson, C.; Kannan, S. Traumatic Injury Leads to Inflammation and Altered Tryptophan Metabolism in the Juvenile Rabbit Brain. J. Neurotrauma 2019, 36, 74-86. [CrossRef] [PubMed]

170. Adelson, P.D.; Jenkins, L.W.; Hamilton, R.L.; Robichaud, P.; Tran, M.P.; Kochanek, P.M. Histopathologic Response of the Immature Rat to Diffuse Traumatic Brain Injury. J. Neurotrauma 2001, 18, 967-976. [CrossRef]

171. Huh, J.W.; Widing, A.G.; Raghupathi, R. Midline brain injury in the immature rat induces sustained cognitive deficits, bihemispheric axonal injury and neurodegeneration. Exp. Neurol. 2008, 213, 84-92. [CrossRef]

172. Russell, K.L.; Berman, N.E.J.; Gregg, P.R.A.; Levant, B. Fish oil improves motor function, limits blood-brain barrier disruption, and reduces Mmp9 gene expression in a rat model of juvenile traumatic brain injury. Prostaglandins Leukot. Essent. Fat. Acids 2014, 90, 5-11. [CrossRef]

173. Schober, M.E.; Requena, D.F.; Abdullah, O.M.; Casper, T.C.; Beachy, J.; Malleske, D.; Pauly, J.R. Dietary Docosahexaenoic Acid Improves Cognitive Function, Tissue Sparing, and Magnetic Resonance Imaging Indices of Edema and White Matter Injury in the Immature Rat after Traumatic Brain Injury. J. Neurotrauma 2016, 33, 390-402. [CrossRef] [PubMed]

174. Simon, D.W.; Aneja, R.K.; Alexander, H.; Bell, M.J.; Bayır, H.; Kochanek, P.M.; Clark, R.S.B. Minocycline Attenuates High Mobility Group Box 1 Translocation, Microglial Activation, and Thalamic Neurodegeneration after Traumatic Brain Injury in Post-Natal Day 17 Rats. J. Neurotrauma 2018, 35, 130-138. [CrossRef] [PubMed]

175. Schober, M.E.; Requena, D.F.; Casper, T.C.; Velhorst, A.K.; Lolofie, A.; McFarlane, K.E.; Otto, T.E.; Terry, C.; Gensel, J.C. Docosahexaenoic acid decreased neuroinflammation in rat pups after controlled cortical impact. Exp. Neurol. 2019, $320,112971$. [CrossRef] [PubMed]

176. Diaz-Chávez, A.; Lajud, N.; Roque, A.; Cheng, J.P.; Meléndez-Herrera, E.; Valdéz-Alarcón, J.J.; Bondi, C.O.; Kline, A.E. Early life stress increases vulnerability to the sequelae of pediatric mild traumatic brain injury. Exp. Neurol. 2020, 329, 113318. [CrossRef]

177. Lajud, N.; Roque, A.; Cheng, J.P.; Bondi, C.O.; Kline, A.E. Early Life Stress Preceding Mild Pediatric Traumatic Brain Injury Increases Neuroinflammation but Does Not Exacerbate Impairment of Cognitive Flexibility during Adolescence. J. Neurotrauma 2021, 38, 411-421. [CrossRef] [PubMed]

178. D'Ambrosio, R.; Maris, D.O.; Grady, M.S.; Winn, H.R.; Janigro, D. Selective loss of hippocampal long-term potentiation, but not depression, following fluid percussion injury. Brain Res. 1998, 786, 64-79. [CrossRef]

179. Smith, A.C.; Holden, R.C.; Rasmussen, S.M.; Hoane, M.R.; Hylin, M.J. Effects of nicotinamide on spatial memory and inflammation after juvenile traumatic brain injury. Behav. Brain Res. 2019, 364, 123-132. [CrossRef]

180. Fraunberger, E.A.; Dejesus, P.; Zanier, E.R.; Shutt, T.E.; Esser, M.J. Acute and Persistent Alterations of Cerebellar Inflammatory Networks and Glial Activation in a Rat Model of Pediatric Mild Traumatic Brain Injury. J. Neurotrauma 2020, 37, 1315-1330. [CrossRef]

181. Tong, W.; Igarashi, T.; Ferriero, D.M.; Noble, L.J. Traumatic brain injury in the immature mouse brain: Characterization of regional vulnerability. Exp. Neurol. 2002, 176, 105-116. [CrossRef]

182. Lee, S.W.; Jang, M.S.; Jeong, S.H.; Kim, H. Exploratory, cognitive, and depressive-like behaviors in adult and pediatric mice exposed to controlled cortical impact. Clin. Exp. Emerg. Med. 2019, 6, 125-137. [CrossRef] [PubMed]

183. Ouyang, W.; Yan, Q.; Zhang, Y.; Fan, Z. Moderate injury in motor-sensory cortex causes behavioral deficits accompanied by electrophysiological changes in mice adulthood. PLoS ONE 2017, 12, e0171976. [CrossRef] [PubMed]

184. Guilhaume-Correa, F.; Cansler, S.M.; Shalosky, E.M.; Goodman, M.D.; Evanson, N.K. Greater neurodegeneration and behavioral deficits after single closed head traumatic brain injury in adolescent versus adult male mice. J. Neurosci. Res. 2020, 98, 557-570. [CrossRef] [PubMed]

185. Kamper, J.E.; Pop, V.; Fukuda, A.M.; Ajao, D.O.; Hartman, R.E.; Badaut, J. Juvenile traumatic brain injury evolves into a chronic brain disorder: Behavioral and histological changes over 6months. Exp. Neurol. 2013, 250, 8-19. [CrossRef]

186. Badaut, J.; Adami, A.; Huang, L.; Obenaus, A. Noninvasive magnetic resonance imaging stratifies injury severity in a rodent model of male juvenile traumatic brain injury. J. Neurosci. Res. 2019, 98, 129-140. [CrossRef]

187. Gurkoff, G.G.; Giza, C.C.; Hovda, D.A. Lateral fluid percussion injury in the developing rat causes an acute, mild behavioral dysfunction in the absence of significant cell death. Brain Res. 2006, 1077, 24-36. [CrossRef]

188. Pullela, R.; Raber, J.; Pfankuch, T.; Ferriero, D.M.; Claus, C.P.; Koh, S.-E.; Yamauchi, T.; Rola, R.; Fike, J.R.; Noble-Haeusslein, L.J. Traumatic Injury to the Immature Brain Results in Progressive Neuronal Loss, Hyperactivity and Delayed Cognitive Impairments. Dev. Neurosci. 2006, 28, 396-409. [CrossRef] 
189. Semple, B.D.; Canchola, S.A.; Noble-Haeusslein, L.J. Deficits in Social Behavior Emerge during Development after Pediatric Traumatic Brain Injury in Mice. J. Neurotrauma 2012, 29, 2672-2683. [CrossRef]

190. Zamani, A.; O’Brien, T.J.; Kershaw, J.; Johnston, L.A.; Semple, B.D.; Wright, D.K. White matter changes following experimental pediatric traumatic brain injury: An advanced diffusion-weighted imaging investigation. Brain Imaging Behav. 2021. [CrossRef]

191. Kaukas, L.; Krieg, J.; Collins-Praino, L.; Corrigan, F. Effects of Remote Immune Activation on Performance in the 5-Choice Serial Reaction Time Task Following Mild Traumatic Brain Injury in Adolescence. Front. Behav. Neurosci. 2021, 15, 659679. [CrossRef] [PubMed]

192. Hazy, A.; Bochicchio, L.; Oliver, A.; Xie, E.; Geng, S.; Brickler, T.; Xie, H.; Li, L.; Allen, I.C.; Theus, M.H. Divergent age-dependent peripheral immune transcriptomic profile following traumatic brain injury. Sci. Rep. 2019, 9, 8564. [CrossRef] [PubMed]

193. Bailes, J.E.; Mills, J.D. Docosahexaenoic acid reduces traumatic axonal injury in a rodent head injury model. J. Neurotrauma 2010, 27, 1617-1624. [CrossRef] [PubMed]

194. Homsi, S.; Piaggio, T.; Croci, N.; Noble, F.; Plotkine, M.; Marchand-Leroux, C.; Jafarian-Tehrani, M. Blockade of acute microglial activation by minocycline promotes neuroprotection and reduces locomotor hyperactivity after closed head injury in mice: A twelve-week follow-up study. J. Neurotrauma 2010, 27, 911-921. [CrossRef] [PubMed]

195. Statler, K.D.; Alexander, H.; Vagni, V.; Holubkov, R.; Dixon, C.E.; Clark, R.S.B.; Jenkins, L.; Kochanek, P.M. Isoflurane exerts neuroprotective actions at or near the time of severe traumatic brain injury. Brain Res. 2006, 1076, 216-224. [CrossRef] [PubMed]

196. Hoane, M.R.; Pierce, J.L.; Holland, M.A.; Anderson, G.D. Nicotinamide treatment induces behavioral recovery when administered up to 4 hours following cortical contusion injury in the rat. Neuroscience 2008, 154, 861-868. [CrossRef] [PubMed]

197. Norden, D.M.; Godbout, J.P. Review: Microglia of the aged brain: Primed to be activated and resistant to regulation. Neuropathol. Appl. Neurobiol. 2013, 39, 19-34. [CrossRef] [PubMed]

198. Bodnar, C.N.; Roberts, K.N.; Higgins, E.K.; Bachstetter, A.D. A Systematic Review of Closed Head Injury Models of Mild Traumatic Brain Injury in Mice and Rats. J. Neurotrauma 2019, 36, 1683-1706. [CrossRef]

199. Zhu, Z.; Chuckowree, J.A.; Musgrove, R.; Dickson, T.C.; Blizzard, C.A. The pathologic outcomes and efficacy of epothilone treatment following traumatic brain injury is determined by age. Neurobiol. Aging 2020, 93, 85-96. [CrossRef]

200. Ritzel, R.M.; Doran, S.J.; Glaser, E.P.; Meadows, V.E.; Faden, A.I.; Stoica, B.A.; Loane, D.J. Old age increases microglial senescence, exacerbates secondary neuroinflammation, and worsens neurological outcomes after acute traumatic brain injury in mice. Neurobiol. Aging 2019, 77, 194-206. [CrossRef]

201. Early, A.N.; Gorman, A.A.; Van Eldik, L.J.; Bachstetter, A.D.; Morganti, J.M. Effects of advanced age upon astrocyte-specific responses to acute traumatic brain injury in mice. J. Neuroinflammation 2020, 17, 115. [CrossRef]

202. Krukowski, K.; Chou, A.; Feng, X.; Tiret, B.; Paladini, M.-S.; Riparip, L.-K.; Chaumeil, M.; Lemere, C.; Rosi, S. Traumatic Brain Injury in Aged Mice Induces Chronic Microglia Activation, Synapse Loss, and Complement-Dependent Memory Deficits. Int. J. Mol. Sci. 2018, 19, 3753. [CrossRef]

203. Chou, A.; Krukowski, K.; Morganti, J.; Riparip, L.-K.; Rosi, S. Persistent Infiltration and Impaired Response of PeripherallyDerived Monocytes after Traumatic Brain Injury in the Aged Brain. Int. J. Mol. Sci. 2018, 19, 1616. [CrossRef]

204. Timaru-Kast, R.; Luh, C.; Gotthardt, P.; Huang, C.; Schäfer, M.K.; Engelhard, K.; Thal, S.C. Influence of Age on Brain Edema Formation, Secondary Brain Damage and Inflammatory Response after Brain Trauma in Mice. PLoS ONE 2012, 7, e43829. [CrossRef]

205. Timaru-Kast, R.; Gotthardt, P.; Luh, C.; Huang, C.; Hummel, R.; Schäfer, M.K.E.; Thal, S.C. Angiotensin II Receptor 1 Blockage Limits Brain Damage and Improves Functional Outcome After Brain Injury in Aged Animals Despite Age-Dependent Reduction in AT1 Expression. Front. Aging Neurosci. 2019, 11, 63. [CrossRef] [PubMed]

206. Sandhir, R.; Onyszchuk, G.; Berman, N.E.J. Exacerbated glial response in the aged mouse hippocampus following controlled cortical impact injury. Exp. Neurol. 2008, 213, 372-380. [CrossRef] [PubMed]

207. Onyszchuk, G.; LeVine, S.M.; Brooks, W.M.; Berman, N.E.J. Post-acute pathological changes in the thalamus and internal capsule in aged mice following controlled cortical impact injury: A magnetic resonance imaging, iron histochemical, and glial immunohistochemical study. Neurosci. Lett. 2009, 452, 204-208. [CrossRef] [PubMed]

208. Shah, S.A.; Prough, D.S.; Garcia, J.M.; DeWitt, D.S.; Hellmich, H.L. Molecular correlates of age-specific responses to traumatic brain injury in mice. Exp. Gerontol. 2006, 41, 1201-1205. [CrossRef] [PubMed]

209. Morganti, J.M.; Riparip, L.-K.; Chou, A.; Liu, S.; Gupta, N.; Rosi, S. Age exacerbates the CCR2/5-mediated neuroinflammatory response to traumatic brain injury. J. Neuroinflammation 2016, 13, 80. [CrossRef]

210. Kumar, A.; Stoica, B.A.; Sabirzhanov, B.; Burns, M.P.; Faden, A.I.; Loane, D.J. Traumatic brain injury in aged animals increases lesion size and chronically alters microglial/macrophage classical and alternative activation states. Neurobiol. Aging 2013, 34, 1397-1411. [CrossRef]

211. Sun, M.; Brady, R.D.; Casillas-Espinosa, P.M.; Wright, D.K.; Semple, B.D.; Kim, H.A.; Mychasiuk, R.; Sobey, C.G.; O’Brien, T.J.; Vinh, A.; et al. Aged rats have an altered immune response and worse outcomes after traumatic brain injury. Brain. Behav. Immun. 2019, 80, 536-550. [CrossRef]

212. Osiac, E.; Mitran, S.I.; Manea, C.N.; Cojocaru, A.; Rosu, G.C.; Osiac, M.; Pirici, D.N.; Bălșeanu, A.T.; Cătălin, B. Optical coherence tomography microscopy in experimental traumatic brain injury. Microsc. Res. Tech. 2021, 84, 422-431. [CrossRef]

213. Islam, M.B.A.R.; Davis, B.T.; Kando, M.J.; Mao, Q.; Procissi, D.; Weiss, C.; Schwulst, S.J. Differential neuropathology and functional outcome after equivalent traumatic brain injury in aged versus young adult mice. Exp. Neurol. 2021, 341, 113714. [CrossRef] 
214. Onyszchuk, G.; He, Y.-Y.; Berman, N.E.J.; Brooks, W.M. Detrimental effects of aging on outcome from traumatic brain injury: A behavioral, magnetic resonance imaging, and histological study in mice. J. Neurotrauma 2008, 25, 153-171. [CrossRef]

215. Shao, C.X.; Roberts, K.N.; Markesbery, W.R.; Scheff, S.W.; Lovell, M.A. Oxidative stress in head trauma in aging. Free Radic. Biol. Med. 2006, 41, 77-85. [CrossRef]

216. Swan, A.A.; Chandrashekar, R.; Beare, J.; Hoane, M.R. Preclinical Efficacy Testing in Middle-Aged Rats: Nicotinamide, a Novel Neuroprotectant, Demonstrates Diminished Preclinical Efficacy after Controlled Cortical Impact. J. Neurotrauma 2011, 28, 431-440. [CrossRef] [PubMed]

217. Hoane, M.R.; Lasley, L.A.; Akstulewicz, S.L. Middle age increases tissue vulnerability and impairs sensorimotor and cognitive recovery following traumatic brain injury in the rat. Behav. Brain Res. 2004, 153, 189-197. [CrossRef] [PubMed]

218. Hamm, R.J.; White-Gbadebo, D.M.; Lyeth, B.G.; Jenkins, L.W.; Hayes, R.L. The Effect of Age on Motor and Cognitive Deficits after Traumatic Brain Injury in Rats. Neurosurgery 1992, 31, 1072-1078. [CrossRef] [PubMed]

219. Gupte, R.; Christian, S.; Keselman, P.; Habiger, J.; Brooks, W.M.; Harris, J.L. Evaluation of taurine neuroprotection in aged rats with traumatic brain injury. Brain Imaging Behav. 2019, 13, 461-471. [CrossRef] [PubMed]

220. Itoh, T.; Imano, M.; Nishida, S.; Tsubaki, M.; Mizuguchi, N.; Hashimoto, S.; Ito, A.; Satou, T. Increased apoptotic neuronal cell death and cognitive impairment at early phase after traumatic brain injury in aged rats. Brain Struct. Funct. 2013, 218, 209-220. [CrossRef]

221. Su, Y.; Fan, W.; Ma, Z.; Wen, X.; Wang, W.; Wu, Q.; Huang, H. Taurine improves functional and histological outcomes and reduces inflammation in traumatic brain injury. Neuroscience 2014, 266, 56-65. [CrossRef]

222. Chuckowree, J.A.; Zhu, Z.; Brizuela, M.; Lee, K.M.; Blizzard, C.A.; Dickson, T.C. The microtubule-modulating drug epothilone D alters dendritic spine morphology in a mouse model of mild traumatic brain injury. Front. Cell. Neurosci. 2018, 12, 223. [CrossRef]

223. Niraula, A.; Sheridan, J.F.; Godbout, J.P. Microglia Priming with Aging and Stress. Neuropsychopharmacology 2017, 42, 318-333. [CrossRef] [PubMed]

224. Harper, M.M.; Hedberg-Buenz, A.; Herlein, J.; Abrahamson, E.E.; Anderson, M.G.; Kuehn, M.H.; Kardon, R.H.; Poolman, P.; Ikonomovic, M.D. Blast-mediated traumatic brain injury exacerbates retinal damage and amyloidosis in the APPswePSEND19e mouse model of alzheimer's disease. Investig. Ophthalmol. Vis. Sci. 2019, 60, 2716-2725. [CrossRef]

225. Szarka, N.; Toth, L.; Czigler, A.; Kellermayer, Z.; Ungvari, Z.; Amrein, K.; Czeiter, E.; Bali, Z.K.; Tadepalli, S.A.; Wahr, M.; et al. Single Mild Traumatic Brain Injury Induces Persistent Disruption of the Blood-Brain Barrier, Neuroinflammation and Cognitive Decline in Hypertensive Rats. Int. J. Mol. Sci. 2019, 20, 3223. [CrossRef] [PubMed]

226. Collins, J.M.; King, A.E.; Woodhouse, A.; Kirkcaldie, M.T.K.; Vickers, J.C. Age Moderates the Effects of Traumatic Brain Injury on Beta-Amyloid Plaque Load in APP/PS1 Mice. J. Neurotrauma 2019, 36, 1876-1889. [CrossRef] [PubMed]

227. Cheng, W.H.; Martens, K.M.; Bashir, A.; Cheung, H.; Stukas, S.; Gibbs, E.; Namjoshi, D.R.; Button, E.B.; Wilkinson, A.; Barron, C.J.; et al. CHIMERA repetitive mild traumatic brain injury induces chronic behavioural and neuropathological phenotypes in wild-type and APP/PS1 mice. Alzheimer's Res. Ther. 2019, 11, 6. [CrossRef]

228. Kaukas, L.; Holmes, J.L.; Rahimi, F.; Collins-Praino, L.; Corrigan, F. Injury during adolescence leads to sex-specific executive function deficits in adulthood in a pre-clinical model of mild traumatic brain injury. Behav. Brain Res. 2021, 402, 113067. [CrossRef]

229. Giannetto, M.; Xia, M.; Stæger, F.F.; Metcalfe, T.; Vinitsky, H.S.; Dang, J.A.M.L.; Xavier, A.L.R.; Kress, B.T.; Nedergaard, M.; Hablitz, L.M. Biological sex does not predict glymphatic influx in healthy young, middle aged or old mice. Sci. Rep. 2020, 10(1), 16073. [CrossRef]

230. Dong, H.; Zhang, X.; Wang, Y.; Zhou, X.; Qian, Y.; Zhang, S. Suppression of Brain Mast Cells Degranulation Inhibits Microglial Activation and Central Nervous System Inflammation. Mol. Neurobiol. 2017, 54, 997-1007. [CrossRef]

231. Thau-Zuchman, O.; Ingram, R.; Harvey, G.G.; Cooke, T.; Palmas, F.; Pallier, P.N.; Brook, J.; Priestley, J.V.; Dalli, J.; Tremoleda, J.L.; et al. A single injection of docosahexaenoic acid induces a pro-resolving lipid mediator profile in the injured tissue and a long-lasting reduction in neurological deficit after traumatic brain injury in mice. J. Neurotrauma 2020, 37, 66-79. [CrossRef] [PubMed]

232. Zhang, Z.; Zhang, Z.; Artelt, M.; Burnet, M.; Schluesener, H.J. Dexamethasone attenuates early expression of three molecules associated with microglia/macrophages activation following rat traumatic brain injury. Acta Neuropathol. 2007, 113, 675-682. [CrossRef] [PubMed]

233. Jeong, D.U.; Bae, S.; Macks, C.; Whitaker, J.; Lynn, M.; Webb, K.; Lee, J.S. Hydrogel-mediated local delivery of dexamethasone reduces neuroinflammation after traumatic brain injury. Biomed. Mater. 2021, 16, 035002. [CrossRef] [PubMed]

234. Hoane, M.R.; Akstulewicz, S.L.; Toppen, J. Treatment with Vitamin B3 Improves Functional Recovery and Reduces GFAP Expression following Traumatic Brain Injury in Rats. J. Neurotrauma 2003, 20, 1189-1199. [CrossRef]

235. Hsieh, C.L.; Niemi, E.C.; Wang, S.H.; Lee, C.C.; Bingham, D.; Zhang, J.; Cozen, M.L.; Charo, I.; Huang, E.J.; Liu, J.; et al. CCR2 deficiency impairs macrophage infiltration and improves cognitive function after traumatic brain injury. J. Neurotrauma 2014, 31 , 1677-1688. [CrossRef]

236. Sun, M.; Zhao, Y.; Gu, Y.; Zhang, Y. Protective effects of taurine against closed head injury in rats. J. Neurotrauma 2015, 32, 66-74. [CrossRef] [PubMed]

237. Cross, D.J.; Garwin, G.G.; Cline, M.M.; Richards, T.L.; Yarnykh, V.; Mourad, P.D.; Ho, R.J.Y.; Minoshima, S. Paclitaxel improves outcome from traumatic brain injury. Brain Res. 2015, 1618, 299-308. [CrossRef] [PubMed] 